\title{
Chemoselective Cross Metathesis of Bishomoallylic Alcohols: Rapid Access to Fragment A of the Cryptophycins.
}

\author{
Mark Lautens ${ }^{*}$, Matthew L. Maddess. \\ 80 St. George Street, Davenport Research Laboratories, Department of Chemistry, \\ University of Toronto, Toronto, Ontario, M5S 3H6, Canada \\ ”mlautens@alchemy.chem.utoronto.ca
}

\section{Supplementary Material}

The following includes representative experimental procedures and details for isolation of compounds. Full characterisation of all novel, and partial characterisation of known, compounds presented in the report are described along with associated intermediates involved in their synthesis.

${ }^{1} \mathrm{H}$ NMR were recorded using Varian instruments at 300,400 or $500 \mathrm{MHz},{ }^{13} \mathrm{C}$ NMR were recorded using Varian instruments at 75,100 , or $125 \mathrm{MHz},{ }^{19} \mathrm{~F}$ NMR were recorded using Varian instruments at 282, or $376 \mathrm{MHz}$. NMR shifts are reported relative to a TMS internal standard or relative to $\mathrm{BF}_{3}{ }^{\bullet} \mathrm{OEt}_{2}$ for ${ }^{19} \mathrm{~F}$. IR spectra were obtained using a Perkin Elmer FT-IR spectrometer (spectrum 1000). High-resolution mass spectra were obtained on a VG 70-250S (double focusing) mass spectrometer at $70 \mathrm{eV}$ or an $\mathrm{ABI} / \mathrm{Sciex}$ Qstar mass spectrometer with an ESI source, MS/MS and accurate mass capabilities. HPLC analysis was performed using a Hewlett Packard Series 1100 HPLC with a UV detector and GC analysis was performed using Hewlett Packard Series II Plus gas chromatograph with a FID detector. Melting points were determined using a Fisher Johns melting point apparatus and are uncorrected. Optical rotations were determined using a Perkin Elmer 243B Polarimeter.

Tetrahydrofuran (THF) and ether were distilled from sodium-benzophenone. Pentane, toluene, DCM, and acetonitrile were distilled from calcium hydride or used as ACS reagents if noted. Methanol $(\mathrm{MeOH})$ was distilled from magnesium and catalytic amount of iodine. (1R)- $(+)-\alpha$-Pinene $(91+\%$ ee) and (1S)- $(-)-\alpha-$ Pinene $(87+\%$ ee) were purchased from Aldrich ${ }^{\mathrm{TM}}$ and were short-path distilled before use. $\mathrm{Sc}(\mathrm{OTf})_{3}$ (97\%), bis(tricyclohexylphosphine)benzylidine ruthenium (IV) dichloride (4) and tricyclohexylphosphine[1,3-bis(2,4,6-trimethylphenyl)-4,5-dihydroimidazol-2-ylidene][benzylidine] ruthenium (IV) dichloride (5) were purchased from Strem Chemicals ${ }^{\mathrm{TM}}$ and used as received. AllylMgBr was purchased from Aldrich ${ }^{\mathrm{TM}}$ as a 1.0 $\mathrm{M}$ solution in ether, and was titrated immediately before each use. $\mathrm{BH}_{3} \bullet \mathrm{DMS}$ (10 to 10.2 $\mathrm{M})$ and various other starting materials were purchased from Aldrich ${ }^{\mathrm{TM}}$ and were used as received without further purification.

All reactions were performed under an atmosphere of nitrogen in flame dried glassware using standard syringe-septum techniques unless otherwise noted. 


\section{Collected References for the Cryptophycins}

\section{Reviews}

(a) Tius, M. A. "Handbook of Environmental Chemistry”, Gribble, G. W. Ed., Springer, Berlin, 2003, 3, 265. (b) Hong, J.; Zhang, L. "Frontiers of Biotechnology and Pharmaceuticals", Zhao, K.; Reiner, J.; Chen, S.-H. Eds., Science Press New York Ltd.: New York, 2002, 3, 193. (c) Li, T. Shih, C. "Frontiers of Biotechnology and Pharmaceuticals", Zhao, K.; Reiner, J.; Chem, S.-H. Eds., Science Press New York Ltd.: New York, 2002, 3, 172. (d) Tius, M. A. Tetrahedron 2002, 58, 4343. (e) Eggen, M.-J.; Georg, G. I. Medicinal Res. Rev. 2002, 22, 85. (f) Shih, C.; Teicher, B. A. Current Pharmaceutical Design 2001, 7 , 1259.

\section{Total Syntheses}

(a) Vidya, R.; Eggen, M.-J.; Nair, S. K.; Georg, G. I.; Himes, R. H. J. Org. Chem. 2003, 68, 9687. (b) Ghosh, A. K.; Swanson, L. J. Org. Chem. 2003, 68, 9823. (c) Hoard, D. W.; Moher, E. D.; Martinelli, M.-J.; Norman, B. H. Org. Lett. 2002, 4, 1813. (d) Li, L.-H.; Tius, M. A. Org. Lett. 2002, 4, 1637. (e) Eggen, M.-J.; Nair, S. K.; Georg, G. I. Org. Lett. 2001, 3, 1813. (f) Eggen, M.-J.; Mossman, C. J.; Buck, S. B.; Nair, S. K.; Bhat, L.; Ali, S. M.; Reiff, E. A.; Boge, T. C.; Georg, G. I. J. Org. Chem. 2000, 65, 7792. (g) Christopher, J. A.; Kocienski, P. J.; Kuhl, A.; Bell, R. Synlett 2000, 4, 463. (h) Ghosh, A. K.; Bischoff, A. Org. Lett. 2000, 2, 1573. (i) Liang, J.; Moher, E. D.; Moore, R. E.; Hoard, D. W. J. Org. Chem. 2000, 65, 3143. (j) White, J. D.; Hong, J.; Robarge, L. A. J. Org. Chem. 1999, 64, 6206. (k) White, J. D.; Hong, J.; Robarge, L. A. Tetrahedron Lett. 1998, 39, 8779. (1) Dhokte, U. P.; Khau, V. V.; Hutchison, D. R.; Martinelli, M. J. Tetrahedron Lett. 1998, 39, 8771. (m) Fray, A. H. Tetrahedron Asymm. 1998, 9, 2777. (n) Gardinier, K. M.; Leahy, J. W. J. Org. Chem. 1997, 62, 7098. (o) Salamonczyk, G. M.; Han, KI.; Guo, Z.W.; Shih, C. J. J. Org. Chem. 1996, 61, 6893. (p) Rej, R.; Nguyen, D.; Go, B.; Fortin, S.; Lavallee, J.-F. J. Org. Chem. 1996, 61, 6289. (q) de Muys, J.-M.; Rej, R.; Nguyen, D.; Go, B.; Fortin, S.; Lavallee, J.-F. Bioorg. Med Chem Lett. 1996, 6, 1111. (r) Barrow, R. A.; Hemscheidt, T.; Liang, J.; Paik, S.; Moore, R. E.; Tius, M. A. J. Am. Chem. Soc. 1995, 117, 2479. (s) Kobayashi, M.; Wang, W.; Ohyabu, N.; Kurosu, M.; Kitagawa, I. Koiso, Y.; Iwasaki, S. Tennen Yuki Kagobutsu Toronkai Koen Yoshishu 1995, 37, 601. (t) Kobayashi, M. Wang, W.; Ohyabu, N.; Kurosu, M.; Kitagawa, I. Chem. Pharm. Bull. 1995, 43, 1598. (u) Kobayashi, M.; Kurosu, M.; Wang, W.; Kitawawa, I. Chem. Pharm. Bull. 1994, 42, 2394.

\section{Fragment Syntheses}

(a) Phukan, P.; Sasman, S.; Maier, M. E.; Eur. J. Org. Chem. 2003, 9, 1733. (b) Raghavan, S.; Tony, K. A. J. Org. Chem. 2003, 68, 5002. (c) Pouseet, C.; Haddad, M.; Larcheveque, M. Tetrahedron 2001, 57, 7163. (d) Chakraborty, T. K.; Das, S. J. Ind. Chem. Soc. 1999, 76, 611. (d) Eggen, M.-J.; Georg, G. I. Bioorg. Med. Chem. Lett. 1998, 8, 3177. (e) Varie, D. L.; Brennan, J.; Briggs, B.; Cronin, J. S.; Hay, D. A.; Rieck, J. A.; Zmijewski, M. J.; Tetrahedron Lett. 1988, 39, 8405. (f) Furuyama, M.; Shimizu, I. Tetrahedron Asymm. 1998, 9, 1351. (g) Ali, S. M.; Georg, G. I. Tetrahedron Lett. 1997, $38,1703$.

\section{Analogue Preparation}

(a) Buck, S. B.; Huff, J. K.; Himes, R. H.; Georg, G. I. J. Med. Chem. 2004, 47, 696. (b) Smith, A. B.; Cho, Y. S.; Pettit, R. G.; Hirschmann, R. Tetrahedron 2003, 59, 6991. (c) Al-Awar, R. S.; Ray, J. E.; Schultz, R. M.; Andis, S. L.; Kennedy, J. H.; Moore, R. E.; Golakoti, T.; Subbaraju, G. V.; Gottumukkala, V.; Corbett, T. H. J. Med. Chem. 2003, 46, 2985. (d) Vidya, R.; Eggen, M.-J.; Georg, G. I.; Himes, R. H. Med. Chem. Lett. 2003, 13, 757. (e) Smith, A. B.; Cho, Y. S.; Zawacki, L. E.; Hirschmann, R.; Pettit, G. R. Org. Lett. 2001, 3, 4063. (f) Barrow, R. A.; Moore, R. E.; Li, L.-H.; Tius, M. A. Tetrahedron 2000, 56, 3339. (g) Patel, V. F.; Andris, S. L.; Kennedy, J. H.; Ray, J. E.; Schultz, R. M. J. Med. Chem. 1999, 42, 2588. (h) Varie, D. L.; Shih, C.; Hay, D. A.; Andis, S. L.; Corbett, T. H.; Gossett, L. S.; Janisse, S. K.; Martinelli, M. J.; Moher, E. D.; Schultz, R. M.; Toth, J. E. Bioorg. Med. Chem. Lett. 1999, 9, 369. (i) Shih, C.; Gossett, L. S.; Gruber, J. M; Grossman, C. S.; Andis, S. L.; Richard, M.; Worzalla, J. F.; Corbett, T. H.; Metz, J. T. Bioorg. Med. Chem. Lett. 1999, 9, 69. (j) Norman, B. H.; Hemscheidt, T.; Schultz, R. M.; Andis, S. L. J. Org. Chem. 1988, 63, 5288. (k) Muakami, N.; Tamura, S.; Wang, W.; Takagi, T.; Kobayashi, M. Tetrahedron 2001, 57, 4323. (l) Murakami, N.; Wang, W.; Ohyabu, N.; Ito, T.; Tamura, S.; Aoki, S.; Kobayashi, M.; Kitagawa, I. Tetrahedron 2000, 56, 9121. (m) Murakami, N.; Wang, W.; Tamura, S.; Kobayashi, M. Bioorg. Med. Chem. Lett. 2000, 10, 1823. 
For the Preparation of 7<smiles>OC(C=Cc1ccccc1)CCl</smiles>

(Sup1): (+/-)-(3E)-1-Chloro-4-phenylbut-3-en-2-ol (General Procedure)

A $250 \mathrm{~mL}$ round bottom flask was flame dried under a stream of nitrogen and allowed to cool to room temperature. It was then charged with trans-cinnamaldehyde $(4.76 \mathrm{~mL}, 37.8 \mathrm{mmol})$ and THF $(75 \mathrm{~mL})$. The reaction mixture was cooled to $-78{ }^{\circ} \mathrm{C}$ and chloroiodomethane $(4.13 \mathrm{~mL}, 56.7 \mathrm{mmol})$ was added followed by the slow addition of $n \operatorname{BuLi}(1.6 \mathrm{M}, 23.6 \mathrm{~mL}, 56.7 \mathrm{mmol})$ over 30 minutes. The reaction was maintained at $78{ }^{\circ} \mathrm{C}$ and monitored by TLC. After 1 hour approximately an equal volume of $\mathrm{NH}_{4} \mathrm{Cl}_{\mathrm{aq}}$ was added and the reaction mixture warmed to room temperature. The reaction contents were transferred to a separatory funnel with ether and the organic layer isolated. The aqueous layer was extracted with ether, the combined organics dried with $\mathrm{MgSO}_{4}$, filtered and concentrated in vacuo. The crude residue was purified by flash chromatography (10 to $12.5 \% \mathrm{EtOAc} / \mathrm{Hex}$ ) to afford the product as a colorless oil (yield $=98 \%) ; \mathrm{R}_{f}=0.38(17 \% \mathrm{EtOAc} / \mathrm{Hex})$. This compound yielded spectra data consistent with literature reports, see for example: Latuens, M.; Maddess, M. L.; Effiette, L. O. S.; Ouellet, S. G. Org. Lett. 2002, 4, 83.

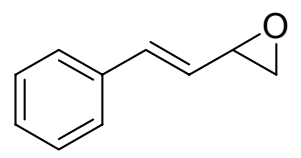

(Sup2): (+/-)-2-[(E)-2-phenylvinyl] oxirane (General Procedure)

A $250 \mathrm{~mL}$ round bottom flask was flame dried under a stream of nitrogen and allowed to cool to room temperature at which time it was charged with THF $(60 \mathrm{~mL})$ and cooled to $0{ }^{\circ} \mathrm{C}$. To this was added sodium hydride $(95 \%, 1.05 \mathrm{~g}, 41.4 \mathrm{mmol})$ followed by sodium iodide $(545 \mathrm{mg}, 3.76 \mathrm{mmol})$. The heterogeneous mixture was stirred for 5 minutes the then Sup1 $(6.87 \mathrm{~g}, 37.6)$, dissolved in THF $(40 \mathrm{~mL})$, was added slowly over approximately 30 minutes via cannula. When the addition was complete the temperature was maintained at $0{ }^{\circ} \mathrm{C}$ and the reaction progress followed by TLC (consumption of starting material monitored, products usually decompose on TLC). After 1 hour $\mathrm{NH}_{4} \mathrm{Cl}_{\mathrm{aq}}$ was added carefully and then the reaction contents were transferred to a separatory funnel using ether. The organic layer was isolated the aqueous layer extracted with ether and the combined organics dried with $\mathrm{MgSO}_{4}$, filtered, and concentrated in vacuo. The crude residue was dried under high vacuum to afford the product as a light yellow oil in good purity $(>95 \%)$ (yield $=89 \%) . \mathrm{R}_{f}=0.58(17 \% \mathrm{EtOAc} / \mathrm{Hex})$. This compound yielded spectra data consistent with literature reports, see for example: Latuens, M.; Maddess, M. L.; Effiette, L. O. S.; Ouellet, S. G. Org. Lett. 2002, 4, 83. 
<smiles>C=CCC(O)CC=Cc1ccccc1</smiles>

\section{(7): (+/-)-(1E)-1-phenylhepta-1,6-dien-4-ol (General Procedure)}

A $100 \mathrm{~mL}$ round bottom flask was flame dried under a stream of nitrogen and allowed to cool to room temperature. It was then charged with Sup2 (1.0 g, $6.84 \mathrm{mmol})$ and THF $(30 \mathrm{~mL})$. To the resulting solution was added potassium allyltrifluoroborate $(1.94 \mathrm{~g}, 13.67 \mathrm{mmol})$ and the heterogeneous mixture was cooled to $0{ }^{\circ} \mathrm{C}$. $\mathrm{BF}_{3} \cdot \mathrm{OEt}_{2}(173$ $\mu \mathrm{L}, 1.36 \mathrm{mmol}$ ) was added dropwise and the reaction was followed by TLC. After 1 hour an approximately equal volume of brine was added and the reaction contents transferred to a separatory funnel with ether. The organic layer was isolated and the aqueous layer extracted with ether. The combined organics were dried with $\mathrm{MgSO}_{4}$ filtered and concentrated in vacuo. The crude residue was purified by flash chromatography $(10 \% \mathrm{EtOAc} / \mathrm{Hex})$ to yield the product as a colorless oil (yield $=84 \%)$. $\mathrm{R}_{f}=0.30\left(5 \%\right.$ EtOAc/ $\left.\mathrm{PhCH}_{3}\right)$. This compound yielded spectra data consistent with literature reports, see for example: Latuens, M.; Maddess, M. L.; Effiette, L. O. S.; Ouellet, S. G. Org. Lett. 2002, 4, 83.<smiles>C=CCC(C/C=C/c1ccccc1)OC(C)=O</smiles>

\section{(8): (+/-)-(3E)-1-Allyl-4-phenylbut-3-enyl acetate}

A $25 \mathrm{~mL}$ round bottom flask was flame dried under a stream of nitrogen and allowed to cool to room temperature. It was then charged with 7 (200 mg, $1.06 \mathrm{mmol})$ and DCM $(10 \mathrm{~mL})$. To the resulting solution was added sequentially DMAP $(20 \mathrm{mg}$, $0.16 \mathrm{mmol}), \mathrm{Et}_{3} \mathrm{~N}(442 \mu \mathrm{L}, 3.19 \mathrm{mmol})$, and $\mathrm{Ac}_{2} \mathrm{O}(301 \mu \mathrm{L}, 3.19 \mathrm{mmol})$ and the mixture left stirring for 14 hours. An approximately equal volume of $\mathrm{NH}_{4} \mathrm{Cl}_{\mathrm{aq}}$ was added and the reaction contents transferred to a separatory funnel with DCM. The organic layer was isolated, the aqueous layer extracted with DCM and the combined organics dried with $\mathrm{MgSO}_{4}$, filtered, and concentrated in vacuo. The crude residue was purified by flash chromatography (0 to $2 \%$ EtOAc/Hex) to afford the product as a colorless oil (yield = 87\%). $\mathrm{R}_{f}=0.31\left(5 \%\right.$ EtOAc/Hex); ${ }^{1} \mathrm{H} \mathrm{NMR}\left(400 \mathrm{MHz}, \mathrm{CDCl}_{3}\right) \delta 7.36-7.27(\mathrm{~m}, 4 \mathrm{H})$, $7.23-7.19(\mathrm{~m}, 1 \mathrm{H}), 6.43(\mathrm{~d}, J=16.0 \mathrm{~Hz}, 1 \mathrm{H}), 6.14(\mathrm{ddd}, J=16.0 \mathrm{~Hz}, 7.2 \mathrm{~Hz}, 7.2 \mathrm{~Hz}$, $1 \mathrm{H}), 5.84-5.72(\mathrm{~m}, 1 \mathrm{H}), 5.13-5.00(\mathrm{~m}, 3 \mathrm{H}), 2.54-2.30(\mathrm{~m}, 4 \mathrm{H}), 2.03(\mathrm{~s}, 3 \mathrm{H}) ;{ }^{13} \mathrm{C}$ NMR $\left(100 \mathrm{MHz}, \mathrm{CDCl}_{3}\right) \delta 107.9,137.5,133.8,133.2,128.7,127.5,126.3,125.4,118.1$, 72.8, 38.3, 37.5, 21.4; FTIR (neat) v 3026, 2952, 1738, 1642, 1434, 1373, 1239, 1025 $\mathrm{cm}^{-1}$; HRMS $(\mathrm{m} / z)$ calculated for $\mathrm{C}_{15} \mathrm{H}_{18} \mathrm{O}_{2} 230.1307$, found 230.1298 .

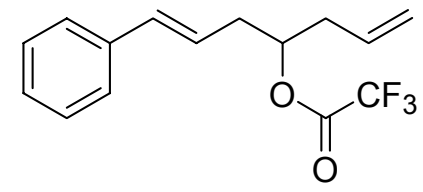

(9): (+/-)-(3E)-1-Allyl-4-phenylbut-3-enyl trifluoroacetate

A $25 \mathrm{~mL}$ round bottom flask was flame dried under a stream of nitrogen and allowed to cool to room temperature. It was then charged with 7 (200 $\mathrm{mg}, 1.06 \mathrm{mmol})$ 
and DCM (10 mL). To the resulting solution was added sequentially DMAP $(20 \mathrm{mg}$, $0.16 \mathrm{mmol}), \mathrm{Et}_{3} \mathrm{~N}(442 \mu \mathrm{L}, 3.19 \mathrm{mmol})$, and trifluoroacetic anhydride $(451 \mu \mathrm{L}, 3.19$ $\mathrm{mmol}$ ) and the mixture left stirring for 14 hours. An approximately equal volume of $\mathrm{NH}_{4} \mathrm{Cl}_{\mathrm{aq}}$ was added and the reaction contents transferred to a separatory funnel with DCM. The organic layer was isolated, the aqueous layer extracted with DCM and the combined organics dried with $\mathrm{MgSO}_{4}$, filtered, and concentrated in vacuo. The crude residue was purified by flash chromatography ( 0 to $2 \%$ EtOAc/Hex) to afford the product as a colorless oil (yield $=76 \%) . \quad \mathrm{R}_{f}=0.47\left(5 \%\right.$ EtOAc/Hex); ${ }^{1} \mathrm{H}$ NMR $(400 \mathrm{MHz}$, $\left.\mathrm{CDCl}_{3}\right) \delta 7.35-7.29(\mathrm{~m}, 4 \mathrm{H}), 7.25-7.21(\mathrm{~m}, 1 \mathrm{H}), 6.48(\mathrm{~d}, J=15.6 \mathrm{~Hz}, 1 \mathrm{H}), 6.09$ (ddd, $J=15.6 \mathrm{~Hz}, 7.6 \mathrm{~Hz}, 7.6 \mathrm{~Hz}, 1 \mathrm{H}), 5.82-5.70(\mathrm{~m}, 1 \mathrm{H}), 5.22-5.13(\mathrm{~m}, 3 \mathrm{H}), 2.65-2.42$ $(\mathrm{m}, 4 \mathrm{H}) ;{ }^{13} \mathrm{C} \mathrm{NMR}\left(75 \mathrm{MHz}, \mathrm{CDCl}_{3}\right) \delta 157.3(\mathrm{q}, J=42 \mathrm{~Hz}), 137.1,134.5,132.2,128.8$, $127.9,126.4,123.5,119.6,114.8(\mathrm{q}, J=284 \mathrm{~Hz}), 77.7,38.0,37.2 ;{ }^{19} \mathrm{~F}$ NMR $(376 \mathrm{MHz}$, $\left.\mathrm{CDCl}_{3}\right) \delta$-75.7; FTIR (neat) v 3028, 1782, 1644, 1386, 1342, 1222, 1162, 967, $746 \mathrm{~cm}^{-1}$; HRMS $(m / z)$ calculated for $\mathrm{C}_{15} \mathrm{H}_{15} \mathrm{O}_{2} \mathrm{~F}_{3} 284.1024$, found 284.1007.<smiles>C=CCC(C/C=C/c1ccccc1)Oc1ccccc1</smiles>

(10): (+/-)-(3E)-1-Allyl-4-phenylbut-3-enyl benzyl ether $(\{[(3 E)-1$-allyl-4-phenylbut3-enyl]oxy\} methyl)benzene

A $25 \mathrm{~mL}$ round bottom flask was flame dried under a stream of nitrogen and allowed to cool to room temperature. It was then charged with $7(150 \mathrm{mg}, 0.80 \mathrm{mmol})$ and anhydrous DMF $(5 \mathrm{~mL})$ and the resulting solution cooled to $0{ }^{\circ} \mathrm{C}$. To this was added $\mathrm{NaH}(95 \%, 30 \mathrm{mg}, 1.2 \mathrm{mmol})$ and the mixture stirred for 10 minutes. Benzyl bromide $(190 \mu \mathrm{L}, 1.60 \mathrm{mmol})$ was added dropwise and the reaction warmed to room temperature where it was stirred for 14 hours. An approximately equal volume of $\mathrm{NH}_{4} \mathrm{Cl}_{\mathrm{aq}}$ was added and the reaction contents transferred to a separatory funnel with ether. The organic layer was isolated, washed three times with $\mathrm{H}_{2} \mathrm{O}$ and then dried with $\mathrm{MgSO}_{4}$, filtered, and concentrated in vacuo. The crude residue was purified by flash chromatography ( 0 to $5 \%$ EtOAc/Hex) to afford the product as a colorless oil (yield $=99 \%) . \quad \mathrm{R}_{f}=0.32(5 \%$ EtOAc/Hex); ${ }^{1} \mathrm{H}$ NMR (300 MHz, $\left.\mathrm{CDCl}_{3}\right) \delta 7.37-7.25(\mathrm{~m}, 9 \mathrm{H}), 7.22-7.16(\mathrm{~m}, 1 \mathrm{H})$, $6.43(\mathrm{~d}, J=15.8 \mathrm{~Hz}, 1 \mathrm{H}), 6.24$ (ddd, $J=15.8 \mathrm{~Hz}, 7.2 \mathrm{~Hz}, 7.2 \mathrm{~Hz}, 1 \mathrm{H}), 5.95-5.80$ (m, $1 \mathrm{H}), 5.16-5.05(\mathrm{~m}, 2 \mathrm{H}), 4.58-4.56(\mathrm{~m}, 2 \mathrm{H}), 3.62-3.54(\mathrm{~m}, 2 \mathrm{H}), 2.50-2.32(\mathrm{~m}, 2 \mathrm{H})$; ${ }^{13} \mathrm{C}$ NMR $\left(75 \mathrm{MHz}, \mathrm{CDCl}_{3}\right) \delta 139.0,137.9,135.1,132.5,128.8,128.7,128.1,127.8$, 127.3, 127.0, 126.3, 117.5, 78.6, 71.4, 38.6, 37.7; v 3028, 2860, 1641, 1496, 1454, $1071 \mathrm{~cm}^{-1}$; HRMS $(\mathrm{m} / \mathrm{z})$ calculated for $\mathrm{C}_{20} \mathrm{H}_{22} \mathrm{O}$ 278.1671 , found 278.1678 .<smiles>C=CCC(C/C=C/c1ccccc1)OC</smiles>

(11): (+/-)-[(1E)-4-(Methoxymethoxy)hepta-1,6-dienyl]benzene

A $25 \mathrm{~mL}$ round bottom flask was flame dried under a stream of nitrogen and allowed to cool to room temperature. It was then charged with 7 (150 mg, $1.06 \mathrm{mmol})$ and anhydrous diisopropyl ethyl amine $(5 \mathrm{~mL})$ and the resulting mixture cooled to $0{ }^{\circ} \mathrm{C}$. 
$\mathrm{MOMCl}(153 \mu \mathrm{L}, 2.0 \mathrm{mmol})$ was added dropwise and reaction was warmed to room temperature where it was left for 14 hours. An approximately equal volume of $\mathrm{NH}_{4} \mathrm{Cl}_{\mathrm{aq}}$ was added and the reaction contents transferred to a separatory funnel with ether. The organic layer was isolated, washed two additional times with $\mathrm{NH}_{4} \mathrm{Cl}_{\mathrm{aq}}$ and then dried with $\mathrm{MgSO}_{4}$, filtered and concentrated in vacuo. The crude residue was purified by flash chromatography ( 2.5 to $5 \% \mathrm{EtOAc} / \mathrm{Hex})$ to afford the product as a colorless oil (yield $=$ $73 \%) . \mathrm{R}_{f}=0.47(10 \% \mathrm{EtOAc} / \mathrm{Hex}) ;{ }^{1} \mathrm{H}$ NMR $\left(400 \mathrm{MHz}, \mathrm{CDCl}_{3}\right) \delta 7.37-7.33(\mathrm{~m}, 2 \mathrm{H})$, $7.32-7.27(\mathrm{~m}, 2 \mathrm{H}), 7.23-7.18(\mathrm{~m}, 1 \mathrm{H}), 6.45(\mathrm{~d}, J=16.0 \mathrm{~Hz}, 1 \mathrm{H}), 6.23$ (ddd, $J=16.0$ $\mathrm{Hz}, 7.2 \mathrm{~Hz}, 7.2 \mathrm{~Hz}, 1 \mathrm{H}), 5.91-5.80(\mathrm{~m}, 1 \mathrm{H}), 5.14-5.07$ (m, 2H), $4.70-4.69$ (m, 2H), $3.80-3.73(\mathrm{~m}, 1 \mathrm{H}), 3.38(\mathrm{~s}, 3 \mathrm{H}), 2.48-2.42(\mathrm{~m}, 2 \mathrm{H}), 2.37-2.32(\mathrm{~m}, 2 \mathrm{H}) ;{ }^{13} \mathrm{C} \mathrm{NMR}$ $\left(100 \mathrm{MHz}, \mathrm{CDCl}_{3}\right) \delta 137.8,134.8,132.6,128.7,126.6,126.2,117.6,95.7,76.7,55.8$, 39.1, 38.1; FTIR (neat) v 2931, 2822, 1495, 1150, 1101, 1039, $917 \mathrm{~cm}^{-1}$; HRMS $(\mathrm{m} / \mathrm{z})$ calculated for $\mathrm{C}_{14} \mathrm{H}_{17} \mathrm{O} 201.1279$, found 201.1270.

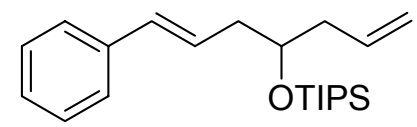

(12): (+/-)-\{[(3E)-1-Allyl-4-phenylbut-3-enyl]oxy\}(triisopropyl)silane

A $25 \mathrm{~mL}$ round bottom flask was flame dried under a stream of nitrogen and allowed to cool to room temperature. It was then charged with $7(200 \mathrm{mg}, 1.06 \mathrm{mmol})$ and DCM $(10 \mathrm{~mL})$. To the resulting solution was added sequentially imidazole (108.2 $\mathrm{mg}, 1.59 \mathrm{mmol})$ and $\mathrm{TIPSCl}(340 \mu \mathrm{L}, 1.59 \mathrm{mmol})$. The mixture was left stirring for 14 hours but conversion was slow so additional imidazole (72 $\mathrm{mg}, 1.06 \mathrm{mmol})$ and TIPSCl $(227 \mu \mathrm{L}, 1.06 \mathrm{mmol})$ were added and stirring continued for 24 hours. An approximately equal volume of $\mathrm{NH}_{4} \mathrm{Cl}_{\text {aq }}$ was added and the reaction contents transferred to a separatory funnel with DCM. The organic layer was isolated, the aqueous layer extracted with DCM and the combined organics dried with $\mathrm{MgSO}_{4}$, filtered, and concentrated in vacuo. The crude residue was purified by flash chromatography (Hex) to afford the product as a colorless oil (yield $=61 \%) . \mathrm{R}_{f}=0.25(\mathrm{Hex}) ;{ }^{1} \mathrm{H}$ NMR $\left(300 \mathrm{MHz}, \mathrm{CDCl}_{3}\right) \delta 7.37-7.27$ (m, 4H), $7.23-7.17(\mathrm{~m}, 1 \mathrm{H}), 6.41(\mathrm{~d}, J=15.9 \mathrm{~Hz}, 1 \mathrm{H}), 6.25$ (ddd, $J=15.9 \mathrm{~Hz}, 7.2 \mathrm{~Hz}$, $7.2 \mathrm{~Hz}, 1 \mathrm{H}), 5.95-5.80(\mathrm{~m}, 1 \mathrm{H}), 5.11-5.03(\mathrm{~m}, 2 \mathrm{H}), 4.03-3.95(\mathrm{~m}, 1 \mathrm{H}), 2.51-2.26$ (m, 4H), $1.10-1.08(\mathrm{~m}, 21 \mathrm{H}) ;{ }^{13} \mathrm{C} \mathrm{NMR}\left(75 \mathrm{MHz}, \mathrm{CDCl}_{3}\right) \delta 138.0,135.1,132.4,128.7$, $127.2, \quad 127.1, \quad 126.2, \quad 117.4, \quad 72.1, \quad 41.6, \quad 40.5, \quad 18.4, \quad 12.8 ; \quad$ FTIR (neat) v 2942, 2866, 1464, 1101, 1066, 914, $883 \mathrm{~cm}^{-1}$; HRMS $(\mathrm{m} / \mathrm{z})$ calculated for $\mathrm{C}_{22} \mathrm{H}_{35} \mathrm{OSi}$ 343.2457, found 343.2434.<smiles>C=CCC(C/C=C/c1ccccc1)O[Sb]</smiles>

(13): (+/-)-\{[(3E)-1-Allyl-4-phenylbut-3-enyl]oxy\}(tert-butyl)dimethylsilane

A $25 \mathrm{~mL}$ round bottom flask was flame dried under a stream of nitrogen and allowed to cool to room temperature. It was then charged with $7(200 \mathrm{mg}, 1.06 \mathrm{mmol})$ and DCM $(10 \mathrm{~mL})$. To the resulting solution was added sequentially imidazole (108.2 $\mathrm{mg}, 1.59 \mathrm{mmol})$ and TBSCl $(249.3 \mathrm{mg}, 1.59 \mathrm{mmol})$. The mixture was left stirring for 14 hours at which time an approximately equal volume of $\mathrm{NH}_{4} \mathrm{Cl}_{\mathrm{aq}}$ was added and the 
reaction contents transferred to a separatory funnel with DCM. The organic layer was isolated, the aqueous layer extracted with DCM and the combined organics dried with $\mathrm{MgSO}_{4}$, filtered, and concentrated in vacuo. The crude residue was purified by flash chromatography (Hex) to afford the product as a colorless oil (yield $=81 \%$ ). $\quad \mathrm{R}_{f}=0.70$ $\left(5 \%\right.$ EtOAc/Hex); ${ }^{1} \mathrm{H}$ NMR $\left(300 \mathrm{MHz}, \mathrm{CDCl}_{3}\right) \delta 7.37-7.26(\mathrm{~m}, 4 \mathrm{H}), 7.23$ - 7.17 (m, $1 \mathrm{H}), 6.39(\mathrm{~d}, J=15.9 \mathrm{~Hz}, 1 \mathrm{H}), 6.22(\mathrm{ddd}, J=15.9 \mathrm{~Hz}, 7.2 \mathrm{~Hz}, 7.2 \mathrm{~Hz}, 1 \mathrm{H}), 5.92-5.77$ $(\mathrm{m}, 1 \mathrm{H}), 5.10-5.02(\mathrm{~m}, 2 \mathrm{H}), 3.86-3.77(\mathrm{~m}, 1 \mathrm{H}), 0.90(\mathrm{~s}, 9 \mathrm{H}), 0.06(\mathrm{~s}, 3 \mathrm{H}), 0.05(\mathrm{~s}$, $3 \mathrm{H}) ;{ }^{13} \mathrm{C}$ NMR $\left(75 \mathrm{MHz}, \mathrm{CDCl}_{3}\right) \delta 138.3,135.7,132.2,128.7,127.4,127.2,126.2$, 126.8, 117.3, 72.2, 42.1, 41.0, 26.1, 18.4, -4.2 ; $\quad$ FTIR (neat) v 2929, 2856, 1471, 1254, 1094, 966, 836,775 $\mathrm{cm}^{-1}$; HRMS $(\mathrm{m} / \mathrm{z})$ calculated for $\mathrm{C}_{19} \mathrm{H}_{29} \mathrm{OSi} 301.1988$, found 301.1982 .<smiles>C=CCC(C/C=C/c1ccccc1)O[Pb]</smiles>

\section{(14): (+/-)-\{[(3E)-1-Allyl-4-phenylbut-3-enyl]oxy\}(tert-butyl)diphenylsilane}

A $25 \mathrm{~mL}$ round bottom flask was flame dried under a stream of nitrogen and allowed to cool to room temperature. It was then charged with $7(200 \mathrm{mg}, 1.06 \mathrm{mmol})$ and DCM $(10 \mathrm{~mL})$. To the resulting solution was added sequentially imidazole (108.2 $\mathrm{mg}, 1.59 \mathrm{mmol})$ and TBDPSCl $(407 \mu \mathrm{L}, 1.59 \mathrm{mmol})$. The mixture was left stirring for 14 hours at which time an approximately equal volume of $\mathrm{NH}_{4} \mathrm{Cl}_{\mathrm{aq}}$ was added and the reaction contents transferred to a separatory funnel with DCM. The organic layer was isolated, the aqueous layer extracted with DCM and the combined organics dried with $\mathrm{MgSO}_{4}$, filtered, and concentrated in vacuo. The crude residue was purified by flash chromatography (Hex) to afford the product as a colorless oil (yield $=83 \%$ ). $\mathrm{R}_{f}=0.60$ (5\% EtOAc/Hex); ${ }^{1} \mathrm{H}$ NMR (300 MHz, $\left.\mathrm{CDCl}_{3}\right) \delta 7.78-7.70$ (m, 4H), $7.50-7.20$ (m, $11 \mathrm{H}), 6.36-6.27(\mathrm{~m}, 1 \mathrm{H}), 6.24-6.10(\mathrm{~m}, 1 \mathrm{H}), 5.92-5.74(\mathrm{~m}, 1 \mathrm{H}), 5.10-4.96(\mathrm{~m}, 2 \mathrm{H})$, $4.00-3.88(\mathrm{~m}, 1 \mathrm{H}), 2.50-2.22(\mathrm{~m}, 4 \mathrm{H}), 1.14-1.10(\mathrm{~m}, 9 \mathrm{H}) ;{ }^{13} \mathrm{C}$ NMR $(75 \mathrm{MHz}$, $\left.\mathrm{CDCl}_{3}\right) \delta 138.0,136.3,135.0,134.6,134.6,132.4,129.8,128.7,127.8,127.2,127.1$, 126.3, 117.5, 73.0, 41.3, 40.1, 27.3, 19.7; FTIR (neat) v $3071,2931,2858,1428,1109,966,822 \mathrm{~cm}^{-1}$; HRMS $(\mathrm{m} / \mathrm{z})$ calculated for $\mathrm{C}_{29} \mathrm{H}_{34} \mathrm{OSi}$ 426.2379, found 426.2379.

General Procedure for study of the rate of RCM for Compounds 7 - 14

A $5.0 \mathrm{~mm}$ NMR tube was oven dried for 12 hours then cooled to room temperature in a desiccator. To this was added the substrate $7(18.8 \mathrm{mg}, 0.1 \mathrm{mmol})$ and a septum was attached. $\mathrm{d}_{2}$-DCM $(0.5 \mathrm{~mL})$ was added that also contained a small amount of ether ( $\sim 0.1 \mathrm{mmol}$ - convenient non-overlapping signals) to act as an internal standard via syringe. The tube was placed in the magnet and a ${ }^{1} \mathrm{H}$ NMR spectrum was taken on a Varian $400 \mathrm{MHz}$ instrument (8 scans, 2 second delay time) with a probe temperature of $25{ }^{\circ} \mathrm{C}$ where the ratio of substrate to ether peaks was noted. Grubbs' second generation catalyst (5) was then added as a solution in DCM $(6.4 \mathrm{mg}$ in $0.3 \mathrm{~mL}$ d-DCM, $0.2 \mathrm{~mL}$ added, $5 \mathrm{~mol} \%$ ) and the time was noted. The tube was placed back in the NMR, the 
shims reset, and spectra were taken at the time intervals noted. The integral of the ether peak on the standard ${ }^{1} \mathrm{H}$ NMR (without catalyst) was used to reset the integrals on the first spectra after addition of the catalyst after which they were not changed. The disappearance of the starting material was followed however in nearly all cases consumption was too rapid to yield useful data. In addition the formation of styrene was recorded since it provided consistently resolved signals and was indicative of RCM events. Styrene present in the catalyst was not corrected for however it is a constant variable.

\section{Results}

\begin{tabular}{|c|c|c|c|c|c|c|c|c|}
\hline \multirow[b]{2}{*}{ Time (min) } & \multicolumn{8}{|c|}{ Mol \% Styrene } \\
\hline & $7 *(\mathrm{~mol} \% \mathrm{SM})$ & 8 & 9 & 10 & 11 (mol\% SM) & 12 & 13 & 14 \\
\hline 0 & $0(100)$ & 0 & 0 & 0 & $0(100)$ & 0 & 0 & 0 \\
\hline 3 & $0.07(67)$ & 0.69 & 0.66 & 0.59 & $0.79(35)$ & 0.71 & 0.51 & 0.66 \\
\hline 6 & $0.1(58)$ & 0.65 & 0.62 & 0.55 & 0.73 & 0.68 & 0.69 & 0.62 \\
\hline 9 & $0.16(52)$ & 0.61 & 0.58 & 0.52 & 0.69 & 0.65 & 0.61 & 0.58 \\
\hline 12 & $0.23(46)$ & 0.56 & 0.54 & 0.49 & 0.65 & 0.62 & 0.57 & 0.55 \\
\hline 15 & $0.29(42)$ & 0.53 & 0.5 & 0.46 & 0.6 & 0.58 & 0.53 & 0.53 \\
\hline 18 & 0.33 & 0.5 & 0.47 & 0.43 & 0.58 & 0.55 & 0.51 & 0.52 \\
\hline 21 & 0.36 & 0.46 & 0.45 & 0.41 & 0.55 & 0.53 & 0.5 & 0.52 \\
\hline 24 & 0.41 & 0.46 & 0.44 & 0.39 & 0.5 & 0.49 & 0.5 & 0.52 \\
\hline 27 & 0.43 & 0.45 & 0.43 & 0.37 & 0.49 & 0.47 & 0.5 & 0.51 \\
\hline 30 & 0.44 & 0.44 & 0.43 & 0.37 & 0.49 & 0.45 & 0.5 & 0.51 \\
\hline 33 & 0.46 & 0.44 & 0.43 & 0.35 & 0.48 & 0.43 & 0.49 & 0.51 \\
\hline 36 & 0.47 & 0.42 & 0.42 & 0.36 & 0.46 & 0.42 & 0.49 & 0.5 \\
\hline 39 & 0.5 & 0.42 & 0.41 & 0.35 & 0.46 & 0.42 & 0.49 & 0.5 \\
\hline 42 & 0.49 & 0.42 & 0.41 & 0.35 & 0.46 & 0.41 & 0.48 & 0.49 \\
\hline 45 & 0.5 & 0.41 & 0.41 & 0.34 & 0.46 & 0.41 & 0.48 & 0.49 \\
\hline 48 & 0.52 & 0.41 & 0.4 & 0.34 & 0.45 & 0.41 & 0.47 & 0.49 \\
\hline 51 & 0.53 & 0.41 & 0.4 & 0.33 & 0.45 & 0.4 & 0.47 & 0.49 \\
\hline 54 & 0.52 & 0.41 & 0.4 & 0.33 & 0.44 & 0.4 & 0.46 & 0.49 \\
\hline 57 & 0.52 & 0.41 & 0.4 & 0.33 & 0.44 & 0.4 & 0.46 & 0.48 \\
\hline 60 & 0.52 & 0.41 & 0.39 & 0.34 & 0.45 & 0.4 & 0.46 & 0.49 \\
\hline 63 & 0.52 & 0.41 & 0.39 & 0.34 & 0.45 & 0.39 & 0.46 & 0.48 \\
\hline
\end{tabular}


Formation of Styrene Versus Time as a Function of the Protecting Group for Bishomoallylic Alcohols

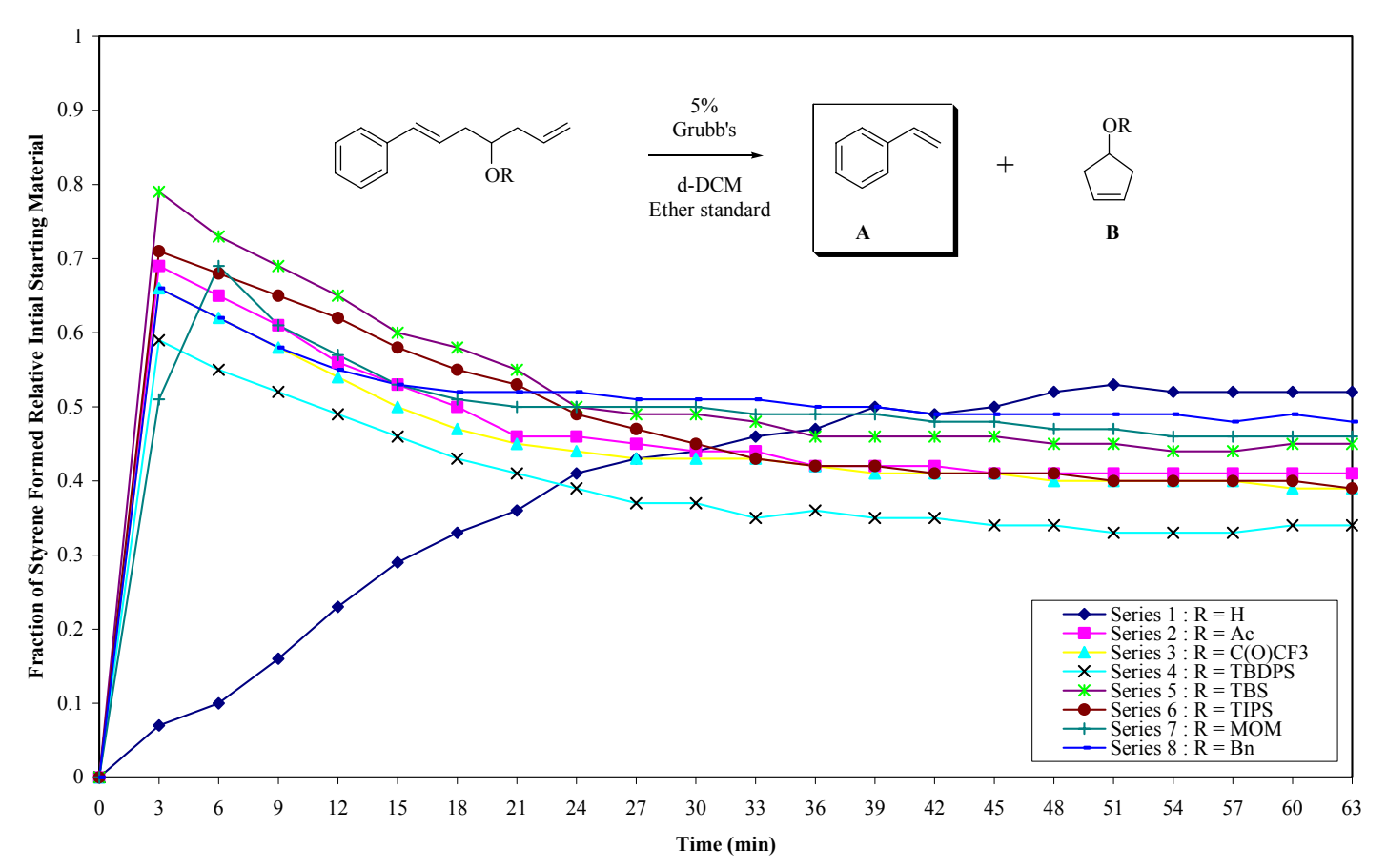<smiles>C=CCC(O)CCCc1ccccc1</smiles>

\section{(15): (+/-)-7-Phenyl-hept-1-en-4-ol}

A $500 \mathrm{~mL}$ round bottom flask was flame dried under a stream of nitrogen and allowed to cool to room temperature. It was then charged with DCM $(200 \mathrm{~mL})$ and anhydrous DMSO $(8.13 \mathrm{~mL}, 114.5 \mathrm{mmol})$. The resulting solution was cooled to $-78{ }^{\circ} \mathrm{C}$ and oxalyl chloride $(5.99 \mathrm{~mL}, 68.7 \mathrm{mmol})$ was introduced dropwise with adequate venting of the reaction vessel. Reaction stirred for 30 minutes by which time the evolution of gases had ceased. 4-Phenyl-1-butanol (2.60 g, $57.3 \mathrm{mmol})$ was added via cannula as a solution in DCM $(40+10 \mathrm{~mL})$ over 30 minutes. Upon completion the reaction was stirred for an additional 30 minutes at which time $\mathrm{Et}_{3} \mathrm{~N}(39.9 \mathrm{~mL}, 286.3$ mmol) was added dropwise initially and then more rapidly near the end of the addition. The reaction mixture was stirred for an additional 30 minutes at $-78{ }^{\circ} \mathrm{C}$ and then the cold bath removed and the vessel allowed too warm slowly to room temperature where it was stirred for 90 minutes. Approximately an equal volume of $\mathrm{NH}_{4} \mathrm{Cl}_{\mathrm{aq}}$ was added and the reaction contents transferred to a separatory funnel with additional DCM. The organic layer was isolated, the aqueous layer back extracted once with DCM and the combined organics dried with $\mathrm{MgSO}_{4}$ filtered and concentrated in vacuo. The crude residue was dried for 3 hours to yield a poorly defined yellowish solid consisting of mainly 4-Phenylbutyraldehyde (Sup3); $\mathrm{R}_{f}=0.54$ (17\% EtOAc/Hex). This compound yielded spectra data consistent with literature reports, see for example: Katohgi, M.; Togo, H. Tetrahedron 2001, 51, 7481. 
The crude product (Sup3) was taken up in THF and cooled to $0{ }^{\circ} \mathrm{C}$. Allyl magnesium bromide $(57.3 \mathrm{~mL}, 57.3 \mathrm{mmol})$ was added over 15 minutes and the reaction stirred for one hour at $0{ }^{\circ} \mathrm{C}$. Approximately an equal volume of $\mathrm{NH}_{4} \mathrm{Cl}_{\mathrm{aq}}$ was added and the reaction contents transferred to a separatory funnel using ether. The organic layer was isolated, the aqueous layer extracted with ether, and the combined organics dried with $\mathrm{MgSO}_{4}$, filtered and concentrated in vacuo. The crude product was purified by flash chromatography $(10 \% \mathrm{EtOAc} / \mathrm{Hex})$ to afford the product as a colorless oil (yield $=30 \%)$. $\mathrm{R}_{f}=0.40(17 \%$ EtOAc/Hex $) ;{ }^{1} \mathrm{H}$ NMR $\left(300 \mathrm{MHz}, \mathrm{CDCl}_{3}\right) \delta 7.32-7.25(\mathrm{~m}, 2 \mathrm{H}), 7.21-$ $7.16(\mathrm{~m}, 3 \mathrm{H}), 5.91-5.54(\mathrm{~m}, 1 \mathrm{H}), 5.17-5.10(\mathrm{~m}, 2 \mathrm{H}), 3.72-3.62(\mathrm{~m}, 1 \mathrm{H}), 2.68-2.62$ $(\mathrm{m}, 2 \mathrm{H}), 2.35-2.25(\mathrm{~m}, 1 \mathrm{H}), 2.19-2.09(\mathrm{~m}, 1 \mathrm{H}), 1.88-1.48(\mathrm{~m}, 5 \mathrm{H}) ;{ }^{13} \mathrm{C}$ NMR $(75$ $\left.\mathrm{MHz}, \mathrm{CDCl}_{3}\right) \delta 140.6,133.0,126.6,126.5,124.0,116.4,68.9,40.4,34.8,34.3,25.9$; FTIR (neat) $~ 3376,2934,1641,1496,1454,1087,996,914,700 \mathrm{~cm}^{-1}$; HRMS $(\mathrm{m} / z)$ calculated for $\mathrm{C}_{13} \mathrm{H}_{18} \mathrm{O}$ 190.1358, found 190.1361.<smiles>C=CCC(CCCc1ccccc1)OC(C)=O</smiles>

(16): (+/-)-1-(3-Phenylpropyl)but-3-enyl acetate

A $25 \mathrm{~mL}$ round bottom flask was flame dried under a stream of nitrogen and allowed to cool to room temperature. It was then charged with 15 (300 $\mathrm{mg}, 1.58 \mathrm{mmol})$ and DCM $(10 \mathrm{~mL})$. To the resulting solution was added sequentially DMAP $(20 \mathrm{mg}$, $0.16 \mathrm{mmol}), \mathrm{Et}_{3} \mathrm{~N}(657 \mu \mathrm{L}, 4.74 \mathrm{mmol})$ and $\mathrm{Ac}_{2} \mathrm{O}(447 \mu \mathrm{L}, 4.74 \mathrm{mmol})$. The mixture was left stirring for 14 hours at which time an approximately equal volume of $\mathrm{NH}_{4} \mathrm{Cl}_{\mathrm{aq}}$ was added and the reaction contents transferred to a separatory funnel with DCM. The organic layer was isolated, the aqueous layer extracted with DCM and the combined organics dried with $\mathrm{MgSO}_{4}$, filtered, and concentrated in vacuo. The crude residue was purified by flash chromatography $(5 \% \mathrm{EtOAc} / \mathrm{Hex})$ to afford the product as a colorless oil (yield = 95\%). $\mathrm{R}_{f}=0.29(5 \% \mathrm{EtOAc} / \mathrm{Hex}) ;{ }^{1} \mathrm{H} \mathrm{NMR}\left(400 \mathrm{MHz}, \mathrm{CDCl}_{3}\right) \delta 7.32-7.26$ $(\mathrm{m}, 2 \mathrm{H}), 7.22-7.16(\mathrm{~m}, 3 \mathrm{H}), 5.82-5.70(\mathrm{~m}, 1 \mathrm{H}), 5.12-5.04(\mathrm{~m}, 2 \mathrm{H}), 5.02-4.94(\mathrm{~m}$, $1 \mathrm{H}), 2.70-2.58(\mathrm{~m}, 2 \mathrm{H}), 2.38-2.26(\mathrm{~m}, 2 \mathrm{H}), 2.05(\mathrm{~s}, 3 \mathrm{H}), 1.74-1.58(\mathrm{~m}, 4 \mathrm{H}) ;{ }^{13} \mathrm{C}$ NMR $\left(100 \mathrm{MHz}, \mathrm{CDCl}_{3}\right) \delta 170.9,142.3,133.9,128.6,128.6,126.1,117.9,73.3,38.9$, 35.8, 33.4, 27.4, 21.4; FTIR (neat) v 3027, 2942, 2861, 1737, 1373, 1242, $1022 \mathrm{~cm}^{-1}$; HRMS $(m / z)$ calculated for $\mathrm{C}_{15} \mathrm{H}_{20} \mathrm{O}_{2} 232.1463$, found 232.1462.<smiles>C=CCC(CCCc1ccccc1)OC(=O)C(F)(F)F</smiles>

(17): (+/-)-1-(3-Phenylpropyl)but-3-enyl trifluoroacetate

A $25 \mathrm{~mL}$ round bottom flask was flame dried under a stream of nitrogen and allowed to cool to room temperature. It was then charged with 15 (300 $\mathrm{mg}, 1.58 \mathrm{mmol})$ and DCM $(10 \mathrm{~mL})$. To the resulting solution was added sequentially DMAP $(20 \mathrm{mg}$, $0.16 \mathrm{mmol}), \mathrm{Et}_{3} \mathrm{~N}(657 \mu \mathrm{L}, 4.74 \mathrm{mmol})$ and trifluoroacetic anhydride $(669 \mu \mathrm{L}, 4.74$ $\mathrm{mmol})$. The mixture was left stirring for 14 hours at which time an approximately equal 
volume of $\mathrm{NH}_{4} \mathrm{Cl}_{\mathrm{aq}}$ was added and the reaction contents transferred to a separatory funnel with DCM. The organic layer was isolated, the aqueous layer extracted with DCM and the combined organics dried with $\mathrm{MgSO}_{4}$, filtered, and concentrated in vacuo. The crude residue was purified by flash chromatography $(5 \% \mathrm{EtOAc} / \mathrm{Hex})$ to afford the product as a colorless oil $($ yield $=99 \%) . \mathrm{R}_{f}=0.39(5 \%$ EtOAc/Hex $) ;{ }^{1} \mathrm{H}$ NMR $\left(400 \mathrm{MHz}, \mathrm{CDCl}_{3}\right) \delta$ $7.34-7.27(\mathrm{~m}, 2 \mathrm{H}), 7.24-7.15(\mathrm{~m}, 3 \mathrm{H}), 5.77-5.65(\mathrm{~m}, 1 \mathrm{H}), 5.18-5.08(\mathrm{~m}, 3 \mathrm{H}), 2.68$ $-2.60(\mathrm{~m}, 2 \mathrm{H}), 2.46-2.34(\mathrm{~m}, 2 \mathrm{H}), 1.80-1.62(\mathrm{~m}, 4 \mathrm{H}) ;{ }^{13} \mathrm{C} \mathrm{NMR}\left(100 \mathrm{MHz}, \mathrm{CDCl}_{3}\right) \delta$ $157.4(\mathrm{q}, J=42 \mathrm{~Hz}), 141.7,132.2,128.7,128.6,126.2,119.3,114.9$ (q, $J=285 \mathrm{~Hz})$, 78.5, 38.5, 35.6, 33.0, 27.0; ${ }^{19} \mathrm{~F}$ NMR (376 $\left.\mathrm{MHz} \mathrm{CDCl}_{3}\right) \delta$-76.1; FTIR (neat) ৩ 3029, 2944, 1782, 1387, 1342, 1222, 1162, $924 \mathrm{~cm}^{-1}$; HRMS $(\mathrm{m} / z)$ calculated for $\mathrm{C}_{15} \mathrm{H}_{17} \mathrm{O}_{2} \mathrm{~F}_{3} 286.1181$, found 286.1188 .<smiles>C=CCC(CCCc1ccccc1)OCc1ccccc1</smiles>

(18): (+/-)-[4-(Benzyloxy)hept-6-enyl]benzene benzyl 1-(3-phenylpropyl)but-3-enyl ether

A $25 \mathrm{~mL}$ round bottom flask was flame dried under a stream of nitrogen and allowed to cool to room temperature. It was then charged with $15(300 \mathrm{mg}, 0.1 .58 \mathrm{mmol})$ and anhydrous DMF $(5 \mathrm{~mL})$ and the resulting solution cooled to $0{ }^{\circ} \mathrm{C}$. To this was added $\mathrm{NaH}(95 \%, 57 \mathrm{mg}, 2.4 \mathrm{mmol})$ and the mixture stirred for 10 minutes. Benzyl bromide $(373 \mu \mathrm{L}, 3.14 \mathrm{mmol})$ was added dropwise and the reaction warmed to room temperature where it was stirred for 14 hours. An approximately equal volume of $\mathrm{NH}_{4} \mathrm{Cl}_{\mathrm{aq}}$ was added and the reaction contents transferred to a separatory funnel with ether. The organic layer was isolated, washed three times with $\mathrm{H}_{2} \mathrm{O}$ and then dried with $\mathrm{MgSO}_{4}$, filtered, and concentrated in vacuo. The crude residue was purified by flash chromatography $(3 \mathrm{x} 0$ to $2.5 \% \mathrm{EtOAc} / \mathrm{Hex})$ to afford the product as a colorless oil (yield $=53 \%) . \quad \mathrm{R}_{f}=0.38(5 \%$ EtOAc/Hex); ${ }^{1} \mathrm{H}$ NMR $\left(300 \mathrm{MHz}, \mathrm{CDCl}_{3}\right) \delta 7.42-7.28(\mathrm{~m}, 7 \mathrm{H}), 7.24-7.17(\mathrm{~m}, 3 \mathrm{H})$, $5.95-5.80(\mathrm{~m}, 1 \mathrm{H}), 5.16-5.05(\mathrm{~m}, 2 \mathrm{H}), 4.59(\mathrm{~d}, J=11.4 \mathrm{~Hz}, 1 \mathrm{H}), 4.50(\mathrm{~d}, J=11.4 \mathrm{~Hz}$, $1 \mathrm{H}), 3.54-3.45(\mathrm{~m}, 1 \mathrm{H}), 2.66-2.58(\mathrm{~m}, 2 \mathrm{H}), 2.40-2.32(\mathrm{~m}, 2 \mathrm{H}), 1.89-1.54(\mathrm{~m}, 4 \mathrm{H})$; ${ }^{13} \mathrm{C}$ NMR $\left(75 \mathrm{MHz}, \mathrm{CDCl}_{3}\right) \delta 142.8,139.1,135.2,128.7,128.6,128.5,128.0,121.8$, 126.0, $\quad 117.2, \quad 78.6, \quad 71.2, \quad 38.5, \quad 36.2, \quad 33.7, \quad 27.4$; FTIR (neat) $\cup$ 3064, 3028, 2936, 2860, 1496, 1454, 1094, $913 \mathrm{~cm}^{-1}$; HRMS $(\mathrm{m} / \mathrm{z})$ calculated for $\mathrm{C}_{20} \mathrm{H}_{24} \mathrm{O} 280.1827$, found 280.1829 .

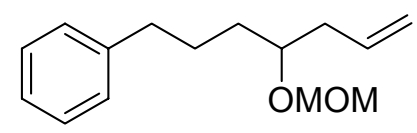

(19): (+/-)-[4-(Methoxymethoxy)hept-6-enyl]benzene

A $25 \mathrm{~mL}$ round bottom flask was flame dried under a stream of nitrogen and allowed to cool to room temperature. It was then charged with $\mathbf{1 5}$ (300 $\mathrm{mg}, 1.58 \mathrm{mmol})$ and anhydrous diisopropyl ethyl amine $(5 \mathrm{~mL})$ and the resulting mixture cooled to $0{ }^{\circ} \mathrm{C}$. $\mathrm{MOMCl}(304 \mu \mathrm{L}, 3.95 \mathrm{mmol})$ was added dropwise and reaction was warmed to room temperature where it was left for 14 hours. An approximately equal volume of $\mathrm{NH}_{4} \mathrm{Cl}_{\mathrm{aq}}$ was added and the reaction contents transferred to a separatory funnel with ether. The 
organic layer was isolated, washed two additional times with $\mathrm{NH}_{4} \mathrm{Cl}_{\mathrm{aq}}$ and then dried with $\mathrm{MgSO}_{4}$, filtered and concentrated in vacuo. The crude residue was purified by flash chromatography ( 2.5 to $5 \% \mathrm{EtOAc} / \mathrm{Hex})$ to afford the product as a colorless oil (yield $=$ $73 \%) . \mathrm{R}_{f}=0.21(5 \% \mathrm{EtOAc} / \mathrm{Hex}) ;{ }^{1} \mathrm{H}$ NMR $\left(400 \mathrm{MHz}, \mathrm{CDCl}_{3}\right) \delta 7.32-7.25(\mathrm{~m}, 2 \mathrm{H})$, $7.22-7.16(\mathrm{~m}, 3 \mathrm{H}), 5.89-5.76(\mathrm{~m}, 1 \mathrm{H}), 5.13-5.03(\mathrm{~m}, 2 \mathrm{H}), 4.70(\mathrm{~d}, J=7.2 \mathrm{~Hz}, 1 \mathrm{H})$, $4.65(\mathrm{~d}, J=7.2 \mathrm{~Hz}, 1 \mathrm{H}), 3.69-3.62(\mathrm{~m}, 1 \mathrm{H}), 3.38(\mathrm{~s}, 3 \mathrm{H}), 2.68-2.61(\mathrm{~m}, 2 \mathrm{H}), 2.34-$ $2.28(\mathrm{~m}, 2 \mathrm{H}), 1.82-1.54(\mathrm{~m}, 4 \mathrm{H}) ;{ }^{13} \mathrm{C}$ NMR $\left(100 \mathrm{MHz}, \mathrm{CDCl}_{3}\right) \delta$ 142.6, 135.0, 128.6, $128.5, \quad 126.0,117.4,95.7,76.9, \quad 55.8,39.2,36.2,34.0,27.4$; FTIR (neat) v 3027, 2934, 1496, 1452, 1147, 1100, 1039, $917 \mathrm{~cm}^{-1}$; HRMS $(\mathrm{m} / \mathrm{z})$ calculated for $\mathrm{C}_{14} \mathrm{H}_{19} \mathrm{O} 203.1436$, found 203.1433.<smiles>C=CCC(CCCc1ccccc1)O[Sb]</smiles>

(20): (+/-)-Triisopropyl\{[1-(3-phenylpropyl)but-3-enyl]oxy\}silane

A $25 \mathrm{~mL}$ round bottom flask was flame dried under a stream of nitrogen and allowed to cool to room temperature. It was then charged with 15 (300 $\mathrm{mg}, 1.58 \mathrm{mmol})$ and anhydrous DMF $(5 \mathrm{~mL})$ and the resulting solution cooled to $0{ }^{\circ} \mathrm{C}$. To this was added $\mathrm{NaH}(95 \%, 46 \mathrm{mg}, 1.9 \mathrm{mmol})$ and the mixture stirred for 10 minutes. TIPSCl $(407 \mu \mathrm{L}$, $1.90 \mathrm{mmol}$ ) was added dropwise and the reaction warmed to room temperature where it was stirred for 48 hours. An approximately equal volume of $\mathrm{NH}_{4} \mathrm{Cl}_{\mathrm{aq}}$ was added and the reaction contents transferred to a separatory funnel with ether. The organic layer was isolated, washed three times with $\mathrm{H}_{2} \mathrm{O}$ and then dried with $\mathrm{MgSO}_{4}$, filtered, and concentrated in vacuo. The crude residue was purified by flash chromatography $(2.5 \%$ EtOAc/Hex) to afford the product as a colorless oil (yield $=74 \%) . \quad \mathrm{R}_{f}=0.89(2.5 \%$ EtOAc/Hex); ${ }^{1} \mathrm{H}$ NMR (400 MHz, $\left.\mathrm{CDCl}_{3}\right) \delta 7.31-7.24(\mathrm{~m}, 2 \mathrm{H}), 7.21-7.14(\mathrm{~m}, 3 \mathrm{H})$, $5.87-5.75(\mathrm{~m}, 1 \mathrm{H}), 5.06-4.99(\mathrm{~m}, 2 \mathrm{H}), 3.92-3.84(\mathrm{~m}, 1 \mathrm{H}), 2.66-2.54(\mathrm{~m}, 2 \mathrm{H}), 2.32$ $-2.20(\mathrm{~m}, 2 \mathrm{H}), 1.73-1.46(\mathrm{~m}, 4 \mathrm{H}), 1.05(\mathrm{~m}, 21 \mathrm{H}) ;{ }^{13} \mathrm{C} \mathrm{NMR}\left(100 \mathrm{MHz}, \mathrm{CDCl}_{3}\right) \delta$ $142.8,135.3,128.6,128.5,125.9,116.9,72.0,41.5,36.4,36.2,26.7,18.4$, 12.8; FTIR (neat) $v 2866,1463,1049,883,676 \mathrm{~cm}^{-1}$; HRMS $(\mathrm{m} / z)$ calculated for $\mathrm{C}_{22} \mathrm{H}_{37} \mathrm{OSi}$ 345.2614, found 345.2622.<smiles>C=CCC(CCCc1ccccc1)O[Sb](=O)(F)c1ccccc1</smiles>

(21): (+/-)-tert-Butyl(dimethyl)\{[1-(3-phenylpropyl)but-3-enyl]oxy\} silane

A $25 \mathrm{~mL}$ round bottom flask was flame dried under a stream of nitrogen and allowed to cool to room temperature. It was then charged with $15(300 \mathrm{mg}, 1.58 \mathrm{mmol})$ and DCM $(10 \mathrm{~mL})$. To the resulting solution was added sequentially imidazole $(215 \mathrm{mg}$, $3.16 \mathrm{mmol})$ and $\mathrm{TBSCl}(372 \mathrm{mg}, 2.37 \mathrm{mmol})$. The mixture was left stirring for 14 hours at which time an approximately equal volume of $\mathrm{NH}_{4} \mathrm{Cl}_{\mathrm{aq}}$ was added and the reaction contents transferred to a separatory funnel with DCM. The organic layer was isolated, the aqueous layer extracted with DCM and the combined organics dried with $\mathrm{MgSO}_{4}$, filtered, and concentrated in vacuo. The crude residue was purified by flash chromatography $(2.5 \% \mathrm{EtOAc} / \mathrm{Hex})$ to afford the product as a colorless oil (yield $=93 \%)$. 
$\mathrm{R}_{f}=0.33\left(2.5 \%\right.$ EtOAc/Hex); ${ }^{1} \mathrm{H}$ NMR $\left(400 \mathrm{MHz}, \mathrm{CDCl}_{3}\right) \delta 7.30-7.24(\mathrm{~m}, 2 \mathrm{H}), 7.20-$ $7.14(\mathrm{~m}, 3 \mathrm{H}), 5.84-5.73(\mathrm{~m}, 1 \mathrm{H}), 5.05-4.98(\mathrm{~m}, 2 \mathrm{H}), 3.74-3.67(\mathrm{~m}, 1 \mathrm{H}), 2.62-2.56$ (m, 2H), $2.22-2.17(\mathrm{~m}, 2 \mathrm{H}), 1.76-1.56(\mathrm{~m}, 2 \mathrm{H}), 1.54-1.42(\mathrm{~m}, 2 \mathrm{H}), 0.88(\mathrm{~s}, 9 \mathrm{H}), 0.03$ (s, 3H), 0.02 (s, 3H); ${ }^{13} \mathrm{C}$ NMR (100 MHz, $\left.\mathrm{CDCl}_{3}\right) \delta 142.8,135.6,128.6,128.5,125.9$, $116.9, \quad 72.0, \quad 42.1, \quad 36.6, \quad 36.2, \quad 27.2, \quad 26.1, \quad 18.4, \quad-4.2, \quad-4.3$; FTIR (neat) v $2931,2858,1461,1254,1093,912,835,774 \mathrm{~cm}^{-1}$; HRMS $(\mathrm{m} / \mathrm{z})$ calculated for $\mathrm{C}_{19} \mathrm{H}_{31} \mathrm{OSi} 303.2144$, found 303.2142.<smiles>C=CCC(CCCc1ccccc1)O[Sb]</smiles>

\section{(22): (+/-)-tert-Butyl(diphenyl)\{[1-(3-phenylpropyl)but-3-enyl]oxy\}silane}

A $25 \mathrm{~mL}$ round bottom flask was flame dried under a stream of nitrogen and allowed to cool to room temperature. It was then charged with 15 (300 $\mathrm{mg}, 1.58 \mathrm{mmol})$ and DCM $(10 \mathrm{~mL})$. To the resulting solution was added sequentially imidazole $(215 \mathrm{mg}$, $3.16 \mathrm{mmol})$ and TBDPSCl $(607 \mu \mathrm{L}, 2.37 \mathrm{mmol})$. The mixture was left stirring for 14 hours at which time an approximately equal volume of $\mathrm{NH}_{4} \mathrm{Cl}_{\mathrm{aq}}$ was added and the reaction contents transferred to a separatory funnel with DCM. The organic layer was isolated, the aqueous layer extracted with DCM and the combined organics dried with $\mathrm{MgSO}_{4}$, filtered, and concentrated in vacuo. The crude residue was purified by flash chromatography $(2.5 \% \mathrm{EtOAc} / \mathrm{Hex})$ to afford the product as a colorless oil (yield $=95 \%$ ). $\mathrm{R}_{f}=0.29(2.5 \% \mathrm{EtOAc} / \mathrm{Hex}) ;{ }^{1} \mathrm{H}$ NMR $\left(400 \mathrm{MHz}, \mathrm{CDCl}_{3}\right) \delta 7.71-7.64(\mathrm{~m}, 4 \mathrm{H}), 7.47-$ $7.34(\mathrm{~m}, 6 \mathrm{H}), 7.29-7.23(\mathrm{~m}, 2 \mathrm{H}), 7.20-7.15(\mathrm{~m}, 1 \mathrm{H}), 7.12-7.06(\mathrm{~m}, 1 \mathrm{H}), 5.79-5.68$ (m, 1H), $4.99-4.90(\mathrm{~m}, 2 \mathrm{H}), 3.84-3.77(\mathrm{~m}, 1 \mathrm{H}), 2.50-2.43(\mathrm{~m}, 2 \mathrm{H}), 2.29-2.15(\mathrm{~m}$, $2 \mathrm{H}), \quad 1.66-1.44(\mathrm{~m}, 4 \mathrm{H}), 1.08(\mathrm{~s}, \quad 9 \mathrm{H}) ;{ }^{13} \mathrm{C}$ NMR $\left(100 \mathrm{MHz}, \mathrm{CDCl}_{3}\right)$ $\delta 142.8,136.3,136.2,135.2,134.8,134.7,129.7,128.6,128.4,127.7,127.7,125.8,117.7$ , 72.9, 41.2, 36.1, 35.9, 27.3, 26.9, 19.6; FTIR (neat) v $\mathrm{cm}^{-1}$ 2932, 2858, 1428, 1110, 1064, 740, 701; HRMS ( $\mathrm{m} / \mathrm{z})$ calculated for $\mathrm{C}_{29} \mathrm{H}_{35} \mathrm{OSi} 427.2457$, found 427.2446.

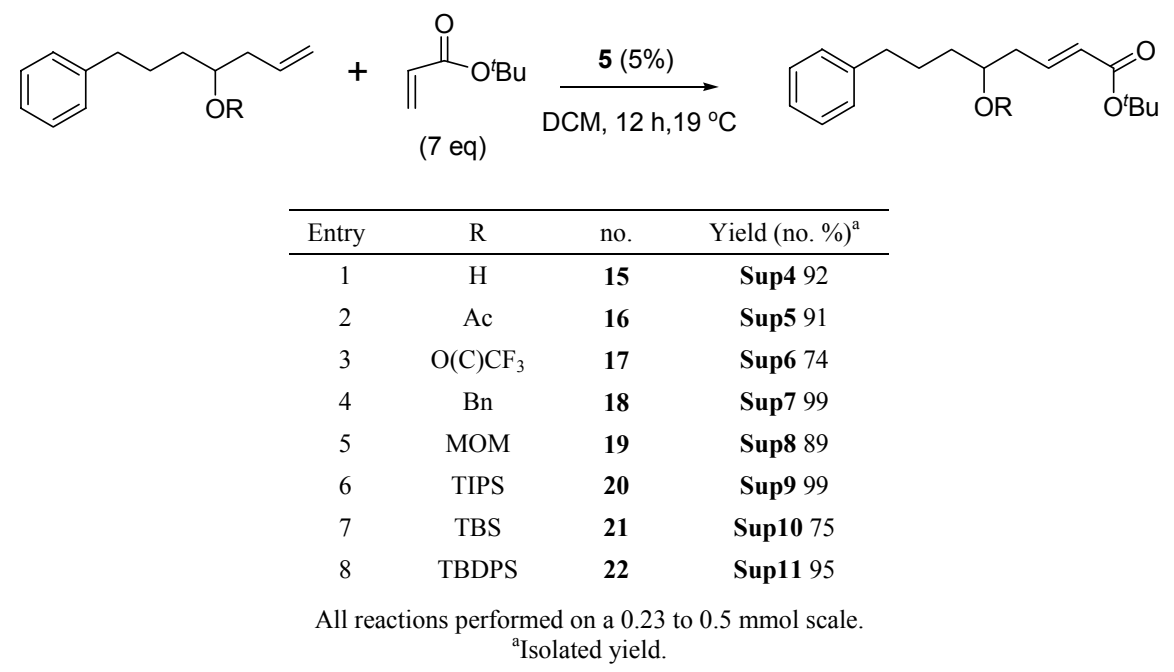

Sup Table 1. Preparation of NMR Standards (Summary). 
For the Preparation of NMR Standards<smiles>CCCOC(=O)/C=C/CC(O)CCCc1ccccc1</smiles>

(Sup4): (+/-)-tert-Butyl (2E)-5-hydroxy-8-phenyloct-2-enoate (General Procedure)

A $5 \mathrm{~mL}$ round bottom flask was flame dried under a stream of nitrogen and allowed to cool to room temperature. It was then charged with 15 (95 mg, $0.5 \mathrm{mmol}), t$ butyl acrylate $(513 \mu \mathrm{L}, 3.5 \mathrm{mmol})$ and DCM $(0.5 \mathrm{~mL})$. To the resulting solution was added Grubbs' second generation catalyst $(5,21 \mathrm{mg}, 0.02 \mathrm{mmol})$ and the dark purple solution stirred for 14 hours. The reaction mixture was then loaded directly on top of a wet column packed with silica gel and purified by flash chromatography (10 to $17 \%$ EtOAc/Hex) to afford the product as a slightly yellow oil (yield $=92 \%) . \mathrm{R}_{f}=0.19(17 \%$ EtOAc/Hex); ${ }^{1} \mathrm{H}$ NMR (400 MHz, $\left.\mathrm{CDCl}_{3}\right) \delta 7.31-7.25(\mathrm{~m}, 2 \mathrm{H}), 7.21-7.15(\mathrm{~m}, 3 \mathrm{H})$, 6.85 (ddd, $J=15.2 \mathrm{~Hz}, 7.6 \mathrm{~Hz}, 7.6 \mathrm{~Hz}, 1 \mathrm{H}), 5.82$ (d, $J=15.2 \mathrm{~Hz}, 1 \mathrm{H}), 3.81-3.70$ (m, $1 \mathrm{H}), 2.67-2.61(\mathrm{~m}, 2 \mathrm{H}), 2.40-2.24(\mathrm{~m}, 2 \mathrm{H}), 1.84-1.61(\mathrm{~m}, 2 \mathrm{H}), 1.59-1.50(\mathrm{~m}, 2 \mathrm{H})$, $1.48 \quad(\mathrm{~s}, \quad 9 \mathrm{H}) ; \quad{ }^{13} \mathrm{C} \quad \mathrm{NMR} \quad\left(100 \quad \mathrm{MHz}, \quad \mathrm{CDCl}_{3}\right)$ $\delta 165.9,143.9,142.4,128.6,128.6,126.0,126.0,80.5,70.7,40.3,36.9,36.0,28.4,27.6$; FTIR (neat) $v \mathrm{~cm}^{-1} 3428,2978,2934,1714,1652,1368,1155,981 ; \operatorname{HRMS}(\mathrm{m} / \mathrm{z})$ calculated for $\mathrm{C}_{14} \mathrm{H}_{18} \mathrm{O}_{3}\left(\mathrm{M}-\mathrm{C}_{4} \mathrm{H}_{9}\right)^{+} 234.1256$, found 234.1262.<smiles>CCCOC(=O)/C=C/CC(CCCc1ccccc1)OC(C)=O</smiles>

(Sup5): (+/-)-tert-Butyl (2E)-5-(acetyloxy)-8-phenyloct-2-enoate

Prepared following the cross metathesis protocol outlined for Sup4 with 16 (116 $\mathrm{mg}, 0.5 \mathrm{mmol})$. The crude reaction mixture was purified by flash chromatography $(2 \mathrm{x} 5$ to $10 \% \mathrm{EtOAc} / \mathrm{Hex}$ ) to afford the product as a colorless oil (yield $=91 \%$ ). $\mathrm{R}_{f}=0.29$ $\left(10 \%\right.$ EtOAc/Hex); ${ }^{1} \mathrm{H}$ NMR (300 MHz, $\left.\mathrm{CDCl}_{3}\right) \delta 7.34-7.26(\mathrm{~m}, 2 \mathrm{H}), 7.24-7.15$ (m, $3 \mathrm{H}), 6.79$ (ddd, $J=15.6 \mathrm{~Hz}, 7.5 \mathrm{~Hz}, 7.5 \mathrm{~Hz}, 1 \mathrm{H}), 5.80(\mathrm{~d}, J=15.6 \mathrm{~Hz}, 1 \mathrm{H}), 5.06-4.95$ $(\mathrm{m}, 1 \mathrm{H}), 2.68-2.58(\mathrm{~m}, 2 \mathrm{H}), 2.50-2.40(\mathrm{~m}, 2 \mathrm{H}), 2.06(\mathrm{~s}, 3 \mathrm{H}), 1.72-1.56(\mathrm{~m}, 4 \mathrm{H}), 1.51$ $(\mathrm{s}, 9 \mathrm{H}) ;{ }^{13} \mathrm{C}$ NMR $\left(75 \mathrm{MHz}, \mathrm{CDCl}_{3}\right) \delta 170.9,165.8,142.5,142.2,128.6,126.1,126.1$, 80.6, 72.5, 36.8, 35.8, 33.4, 28.4, 27.4, 21.4; FTIR (neat) ৩ 2937, 1714, 1655, 1455, $1369,1241,1154,1021,981 \mathrm{~cm}^{-1}$; HRMS $(\mathrm{m} / \mathrm{z})$ calculated for $\mathrm{C}_{20} \mathrm{H}_{29} \mathrm{O}_{4} 333.2066$, found 333.2070 .<smiles>CCCCC(=O)/C=C/CC(CCCc1ccccc1)OC(=O)C(F)(F)F</smiles>

(Sup6): (+/-)-tert-Butyl (2E)-8-phenyl-5-[(trifluoroacetyl)oxy]oct-2-enoate

Prepared following the cross metathesis protocol outlined for Sup4 with 17 (143 $\mathrm{mg}, 0.5 \mathrm{mmol})$. The crude reaction mixture was purified by flash chromatography $(5 \%$ EtOAc/Hex) to afford the product as a colorless oil (yield $=74 \%) . \quad \mathrm{R}_{f}=0.18(5 \%$ 
EtOAc/Hex); ${ }^{1} \mathrm{H}$ NMR (400 MHz, $\left.\mathrm{CDCl}_{3}\right) \delta 7.32-7.26(\mathrm{~m}, 2 \mathrm{H}), 7.23-7.13(\mathrm{~m}, 3 \mathrm{H})$, 6.71 (ddd, $J=15.6 \mathrm{~Hz}, 7.6 \mathrm{~Hz}, 7.6 \mathrm{~Hz}, 1 \mathrm{H}), 5.81(\mathrm{~d}, J=15.6 \mathrm{~Hz}, 1 \mathrm{H}), 5.19-5.11$ (m, $1 \mathrm{H}), 2.68-2.60(\mathrm{~m}, 2 \mathrm{H}), 2.55-2.50(\mathrm{~m}, 2 \mathrm{H}), 1.78-1.62(\mathrm{~m}, 4 \mathrm{H}), 1.49(\mathrm{~s}, 9 \mathrm{H}) ;{ }^{13} \mathrm{C}$ NMR $\left(100 \mathrm{MHz}, \mathrm{CDCl}_{3}\right) \delta 165.3,157.3(\mathrm{q}, J=43 \mathrm{~Hz}), 141.5,140.2,128.7,128.6$, $127.3,126.3,114.8(\mathrm{q}, J=285 \mathrm{~Hz}), 80.8,77.6,36.4,35.5,33.0,28.3,26.9 ;{ }^{19} \mathrm{~F}$ NMR $\left(376 \mathrm{MHz}, \mathrm{CDCl}_{3}\right) \delta$-75.6; FTIR (neat) $\cup \quad 3029,2980,2937,1783,1714,1659,1369$, $1328,1223,1162,983 \mathrm{~cm}^{-1}$; HRMS $(\mathrm{m} / \mathrm{z})$ calculated for $\mathrm{C}_{19} \mathrm{H}_{22} \mathrm{O}_{4} \mathrm{~F}_{3}\left(\mathrm{M}-\mathrm{CH}_{3}\right)^{+} 371.1470$, found 371.1484 .<smiles>CCCOC(=O)/C=C/CC(CCCc1ccccc1)OCc1ccccc1</smiles>

(Sup7): (+/-)-tert-Butyl (2E)-5-(benzyloxy)-8-phenyloct-2-enoate

Prepared following the cross metathesis protocol outlined for Sup4 with 18 (140 $\mathrm{mg}, 0.5 \mathrm{mmol})$. The crude reaction mixture was purified by flash chromatography ( 2.5 to $5 \% \mathrm{EtOAc} / \mathrm{Hex})$ to afford the product as a light yellow oil (yield $=99 \%) . \mathrm{R}_{f}=0.48(10 \%$ EtOAc/Hex); ${ }^{1} \mathrm{H}$ NMR (400 MHz, $\left.\mathrm{CDCl}_{3}\right) \delta 7.38-7.34(\mathrm{~m}, 4 \mathrm{H}), 7.34-7.29(\mathrm{~m}, 3 \mathrm{H})$, $7.24-7.18$ (m, 3H), 6.92 (ddd, $J=16.0 \mathrm{~Hz}, 7.6 \mathrm{~Hz}, 7.6 \mathrm{~Hz}, 1 \mathrm{H}), 5.84(\mathrm{~d}, J=16.0 \mathrm{~Hz}$, $1 \mathrm{H}), 4.57(\mathrm{~d}, J=11.6 \mathrm{~Hz}, 1 \mathrm{H}), 4.50(\mathrm{~d}, J=11.6 \mathrm{~Hz}, 1 \mathrm{H}), 3.60-3.52(\mathrm{~m}, 1 \mathrm{H}), 2.68-$ $2.60(\mathrm{~m}, 2 \mathrm{H}), 2.50-2.40(\mathrm{~m}, 2 \mathrm{H}), 1.83-1.58(\mathrm{~m}, 4 \mathrm{H}), 1.53(\mathrm{~s}, 9 \mathrm{H}) ;{ }^{13} \mathrm{C}$ NMR $(100$ $\left.\mathrm{MHz}, \mathrm{CDCl}_{3}\right) \delta 166.0,144.2,142.5,138.7,128.7,128.6,128.6,128.1,127.9,126.0$, $125.5,80.4,77.9,71.4,36.9,36.1,33.9,28.4,27.3$; FTIR (neat) v 3028, 2977, 2862, $1713,1652,1454,1257,1153,1092 \mathrm{~cm}^{-1}$; HRMS $(\mathrm{m} / z)$ calculated for $\mathrm{C}_{21} \mathrm{H}_{24} \mathrm{O}_{3}$ (M$\left.\mathrm{C}_{4} \mathrm{H}_{9}\right)^{+} 324.1725$, found 324.1721 .<smiles>CCOC(=O)/C=C/CC(CCCc1ccccc1)OC</smiles>

\section{(Sup8): (+/-)-tert-Butyl (2E)-5-(methoxymethoxy)-8-phenyloct-2-enoate}

Prepared following the cross metathesis protocol outlined for Sup4 with 19 (117 $\mathrm{mg}, 0.5 \mathrm{mmol})$. The crude reaction mixture was purified by flash chromatography $(10 \%$ EtOAc/Hex) to afford the product as a light yellow oil (yield $=89 \%) . \quad \mathrm{R}_{f}=0.39(10 \%$ EtOAc/Hex); ${ }^{1} \mathrm{H}$ NMR (300 MHz, $\left.\mathrm{CDCl}_{3}\right) \delta 7.34-7.26(\mathrm{~m}, 2 \mathrm{H}), 7.24-7.16(\mathrm{~m}, 3 \mathrm{H})$, $6.88(\mathrm{dd}, J=15.6 \mathrm{~Hz}, 7.2 \mathrm{~Hz}, 7.2 \mathrm{~Hz}, 1 \mathrm{H}), 5.82(\mathrm{~d}, J=15.6 \mathrm{~Hz}, 1 \mathrm{H}), 4.66(\mathrm{~m}, 2 \mathrm{H}), 3.76$ $-3.66(\mathrm{~m}, 1 \mathrm{H}), 3.38(\mathrm{~s}, 3 \mathrm{H}), 2.70-2.60(\mathrm{~m}, 2 \mathrm{H}), 2.46-2.38(\mathrm{~m}, 2 \mathrm{H}), 1.80-1.52(\mathrm{~m}$, $4 \mathrm{H}), 1.51(\mathrm{~s}, 9 \mathrm{H}) ;{ }^{13} \mathrm{C} \mathrm{NMR}\left(75 \mathrm{MHz}, \mathrm{CDCl}_{3}\right) \delta 165.9,144.0,142.5,128.6,128.6,126.1$, 125.6, 95.6, 80.4, 76.3, 55.9, 37.4, 36.1, 34.3, 28.4, 27.4; FTIR (neat) v 2935, 1714, 1653, 1367, 1149, 1100, $1036 \mathrm{~cm}^{-1}$; HRMS $(\mathrm{m} / z)$ calculated for $\mathrm{C}_{20} \mathrm{H}_{31} \mathrm{O}_{4} 335.2222$, found 335.2222 . 
<smiles>CCOC(=O)/C=C/CC([OH+])CCCc1ccccc1</smiles>

(Sup9): (+/-)-tert-Butyl (2E)-8-phenyl-5-[(triisopropylsilyl)oxy]oct-2-enoate

Prepared following the cross metathesis protocol outlined for Sup4 with 20 (80 $\mathrm{mg}, 0.23 \mathrm{mmol}$ ). The crude reaction mixture was purified by flash chromatography $(2.5 \% \mathrm{EtOAc} / \mathrm{Hex})$ to afford the product as a light brown oil (yield $=99 \%) . \quad \mathrm{R}_{f}=0.34$ (5\% EtOAc/Hex); ${ }^{1} \mathrm{H}$ NMR (400 MHz, $\left.\mathrm{CDCl}_{3}\right) \delta 7.31-7.26(\mathrm{~m}, 2 \mathrm{H}), 7.21-7.15$ (m, $3 \mathrm{H}), 6.89$ (ddd, $J=16.0 \mathrm{~Hz}, 7.2 \mathrm{~Hz}, 7.2 \mathrm{~Hz}, 1 \mathrm{H}) 5.76$ (d, $J=16.0 \mathrm{~Hz}, 1 \mathrm{H}), 4.01-3.92$ $(\mathrm{m}, 1 \mathrm{H}), 2.67-2.58(\mathrm{~m}, 2 \mathrm{H}), 2.44-2.30(\mathrm{~m}, 2 \mathrm{H}), 1.74-1.52(\mathrm{~m}, 4 \mathrm{H}), 1.50(\mathrm{~s}, 9 \mathrm{H}), 1.06$ $(\mathrm{m}, 21 \mathrm{H}) ;{ }^{13} \mathrm{C}$ NMR $\left(100 \mathrm{MHz}, \mathrm{CDCl}_{3}\right) \delta 166.0,144.6,142.5,128.6,128.5,126.0,125.3$, 80.2, 71.6, 39.7, 36.8, 36.2, 28.4, 26.7, 18.4, 12.8; FTIR (neat) ৩ 2943, 2867, 1715, 1462, $1367,1155,1097,985,883 \mathrm{~cm}^{-1}$; HRMS $(\mathrm{m} / z)$ calculated for $\mathrm{C}_{24} \mathrm{H}_{39} \mathrm{O}_{3} \mathrm{Si}\left(\mathrm{M}-\mathrm{C}_{3} \mathrm{H}_{7}\right)^{+}$ 403.2668, found 403.2664.<smiles>CCOC(=O)/C=C/CC(CCCc1ccccc1)O[Sb](=O)(=O)c1ccccc1</smiles>

(Sup10): (+/-)-tert-Butyl (2E)-5-\{[tert-butyl(dimethyl)silyl]oxy\}-8-phenyloct-2-enoate Prepared following the cross metathesis protocol outlined for Sup4 with 21 (152 $\mathrm{mg}, 0.5 \mathrm{mmol})$. The crude reaction mixture was purified by flash chromatography (0 to $2.5 \% \mathrm{EtOAc} / \mathrm{Hex})$ to afford the product as a colorless oil (yield $=75 \%) . \quad \mathrm{R}_{f}=0.34(5 \%$ EtOAc/Hex); ${ }^{1} \mathrm{H}$ NMR (400 MHz, $\left.\mathrm{CDCl}_{3}\right) \delta 7.30-7.24(\mathrm{~m}, 2 \mathrm{H}), 7.20-7.13(\mathrm{~m}, 3 \mathrm{H})$, 6.83 (ddd, $J=16.0 \mathrm{~Hz}, 7.6 \mathrm{~Hz}, 7.6 \mathrm{~Hz}, 1 \mathrm{H}), 5.73(\mathrm{~d}, J=15.6 \mathrm{~Hz}, 1 \mathrm{H}), 3.80-3.76$ (m, $1 \mathrm{H}), 2.63-2.56(\mathrm{~m}, 2 \mathrm{H}), 2.33-2.23(\mathrm{~m}, 2 \mathrm{H}), 1.72-1.46(\mathrm{~m}, 4 \mathrm{H}), 1.48(\mathrm{~s}, 9 \mathrm{H}), 0.87(\mathrm{~s}$, $9 \mathrm{H}), 0.03(\mathrm{~s}, 3 \mathrm{H}), 0.02(\mathrm{~s}, 3 \mathrm{H}) ;{ }^{13} \mathrm{C} \mathrm{NMR}\left(100 \mathrm{MHz}, \mathrm{CDCl}_{3}\right) \delta 166.0,144.9,142.6$, 128.6, 128.5, 126.0, 125.3, 80.2, 71.4, 40.2, 37.1, 36.1, 28.4, 27.1, 26.1, 10.3, -4.3, -4.3; FTIR (neat) v 2932, 2858, 1715, 1459, 1367, 1255, 1155, $1092 \mathrm{~cm}^{-1}$; HRMS (m/z) calculated for $\mathrm{C}_{24} \mathrm{H}_{39} \mathrm{O}_{3} \mathrm{Si} 403.2668$, found 403.2671 .<smiles>CCCOC(=O)/C=C/CC(CCCc1ccccc1)[OH+]S</smiles>

(Sup11): (+/-)-tert-Butyl (2E)-5-\{[tert-butyl(diphenyl)silyl]oxy\}-8-phenyloct-2-enoate

Prepared following the cross metathesis protocol outlined for Sup4 with 22 (214 $\mathrm{mg}, 0.5 \mathrm{mmol})$. The crude reaction mixture was purified by flash chromatography ( 0 to $2.5 \% \mathrm{EtOAc} / \mathrm{Hex}$ ) to afford the product as a light yellow oil (yield $=95 \%$ ). $\quad \mathrm{R}_{f}=0.34$ (5\% EtOAc/Hex); ${ }^{1} \mathrm{H}$ NMR (400 MHz, $\left.\mathrm{CDCl}_{3}\right) \delta 7.68-7.63(\mathrm{~m}, 4 \mathrm{H}), 7.46-7.34(\mathrm{~m}$, $6 \mathrm{H}), 7.27-7.22(\mathrm{~m}, 2 \mathrm{H}), 7.19-7.14(\mathrm{~m}, 1 \mathrm{H}), 7.08-7.04(\mathrm{~m}, 2 \mathrm{H}), 6.78(\mathrm{ddd}, J=15.6$ $\mathrm{Hz}, 7.6 \mathrm{~Hz}, 7.6 \mathrm{~Hz}, 1 \mathrm{H}), 5.64$ (d, $J=15.6 \mathrm{~Hz}, 1 \mathrm{H}), 3.86-3.80(\mathrm{~m}, 1 \mathrm{H}), 2.48-2.40$ (m, $2 \mathrm{H}), 2.32-2.24(\mathrm{~m}, 2 \mathrm{H}), 1.60-1.46(\mathrm{~m}, 4 \mathrm{H}), 1.48(\mathrm{~s}, 9 \mathrm{H}), 1.05(\mathrm{~s}, 9 \mathrm{H}) ;{ }^{13} \mathrm{C} \mathrm{NMR}(100$ $\left.\mathrm{MHz}, \mathrm{CDCl}_{3}\right) \delta 166.0,144.4,142.5,136.2,136.1,129.9,129.8,128.5,128.4,127.8$, $127.8,125.9,125.4,80.2,72.3,39.4,36.3,35.9,28.3,27.3,26.9,19.6$; FTIR (neat) $v$ 2933, 2858, 1714, 1654, 1428, 1367, 1153, 1110, $702 \mathrm{~cm}^{-1}$; HRMS $(\mathrm{m} / z)$ calculated for $\mathrm{C}_{30} \mathrm{H}_{35} \mathrm{O}_{3} \mathrm{Si}\left(\mathrm{M}-\mathrm{C}_{4} \mathrm{H}_{9}\right)^{+} 471.2355$, found 471.2342. 
General Procedure for study of the rate of CM for Compounds Sup4-11

A stock solution of $t$-butyl acrylate $(880 \mu \mathrm{L}, 6 \mathrm{mmol})$ in $\mathrm{C}_{6} \mathrm{D}_{6}(9.0 \mathrm{~mL})$ that also contained ether $(315 \mu \mathrm{L}, 3 \mathrm{mmol})$ as an internal standard was prepared in a sealed Wheaton bottle that was stored at $-20{ }^{\circ} \mathrm{C}$ when not in use.

A $5.0 \mathrm{~mm}$ NMR tube was oven dried for 12 hours then cooled to room temperature in a desiccator. To this was added the substrate $\mathbf{1 5}(18.8 \mathrm{mg}, 0.1 \mathrm{mmol})$ and a septum was attached. To this was added $0.5 \mathrm{~mL}$ of the stock solution via syringe. The tube was placed in the magnet and a ${ }^{1} \mathrm{H}$ NMR spectra was taken on a Varian $400 \mathrm{MHz}$ instrument ( 8 scans, 2 second delay time) with a probe temperature of $25^{\circ} \mathrm{C}$ where the ratio of substrate to ether peaks was noted. Grubbs' second generation catalyst (5) was then added as a solution in $\mathrm{C}_{6} \mathrm{D}_{6}\left(6.4 \mathrm{mg}\right.$ in $0.3 \mathrm{~mL} \mathrm{C}_{6} \mathrm{D}_{6}, 0.2 \mathrm{~mL}$ added, $\left.5 \mathrm{~mol} \%\right)$ and the time was noted. The tube was placed back in the NMR, the shims reset, and spectra were taken at the time intervals indicated. The integral of the ether peak on the standard ${ }^{1} \mathrm{H}$ NMR (without catalyst) was used to reset the integrals on the first spectra after addition of the catalyst after which they were not changed. The appearance of the desired product (Sup4) was followed by reference to conveniently resolved signals of the previously prepared pure product (Sup4).

\section{Results}

NMR Kinetic Study of the Rate of Cross Metathesis as a Function of Protecting Group.

\begin{tabular}{|c|c|c|c|c|c|c|c|c|c|c|c|}
\hline \multicolumn{12}{|c|}{ Uncorrected Data } \\
\hline 5 & 0.02 & 0.11 & 0.07 & 0.24 & 0.14 & 0.07 & 0.2 & 0.0815 & 0.125 & 0.09 & 0.09 \\
\hline 11 & 0.05 & 0.16 & 0.12 & 0.32 & 0.22 & 0.1 & 0.28 & 0.17 & 0.155 & 0.15 & 0.15 \\
\hline 14 & 0.07 & 0.18 & 0.14 & 0.37 & 0.25 & 0.1 & 0.32 & 0.21 & 0.175 & 0.18 & 0.17 \\
\hline 17 & 0.09 & 0.22 & 0.17 & 0.4 & 0.28 & 0.12 & 0.345 & 0.255 & 0.195 & 0.21 & 0.2 \\
\hline 26 & 0.14 & 0.29 & 0.24 & 0.49 & 0.35 & 0.16 & 0.41 & 0.36 & 0.24 & 0.32 & 0.27 \\
\hline 29 & 0.16 & 0.3 & 0.26 & 0.51 & 0.37 & 0.17 & 0.435 & 0.385 & 0.255 & 0.35 & 0.29 \\
\hline \multicolumn{12}{|c|}{ Uncorrected Data } \\
\hline $15(1)$ & Slope & 0.0057 & Intercept & -0.0095 & $\mathrm{R} 2$ & 0.9958 & & & & & \\
\hline 21 & Slope & 0.0041 & Intercept & 0.049 & R2 & 0.9618 & & & & & \\
\hline 20 & Slope & 0.0096 & Intercept & 0.1695 & $\mathrm{R} 2$ & 0.9761 & & & & & \\
\hline 18 & Slope & 0.013 & Intercept & 0.0252 & $\mathrm{R} 2$ & 0.993 & & & & & \\
\hline 19 & Slope & 0.0055 & Intercept & 0.0971 & $\mathrm{R} 2$ & 0.9977 & & & & & \\
\hline 16 & Slope & 0.0109 & Intercept & 0.0304 & $\mathrm{R} 2$ & 0.997 & & & & & \\
\hline 17 & Slope & 0.0083 & Intercept & 0.0539 & $\mathrm{R} 2$ & 0.9968 & & & & & \\
\hline \multicolumn{12}{|c|}{ Corrected Data (intercept set to zero, and absolute values recalculated) } \\
\hline $15(1)$ & $\mathrm{k}(\mathrm{s}-1)$ & 0.0057 & R2 & 0.9958 & Average & 0.0074 & Error & 0.00146 & & & \\
\hline $15(2)$ & $\mathrm{k}(\mathrm{s}-1)$ & 0.0084 & $\mathrm{R} 2$ & 0.9873 & & & & & & & \\
\hline $15(3)$ & $\mathrm{k}(\mathrm{s}-1)$ & 0.008 & $\mathrm{R} 2$ & 0.9982 & & & & & & & \\
\hline 17 & $\mathrm{k}(\mathrm{s}-1)$ & 0.0083 & $\mathrm{R} 2$ & 0.9968 & & & & & & & \\
\hline
\end{tabular}



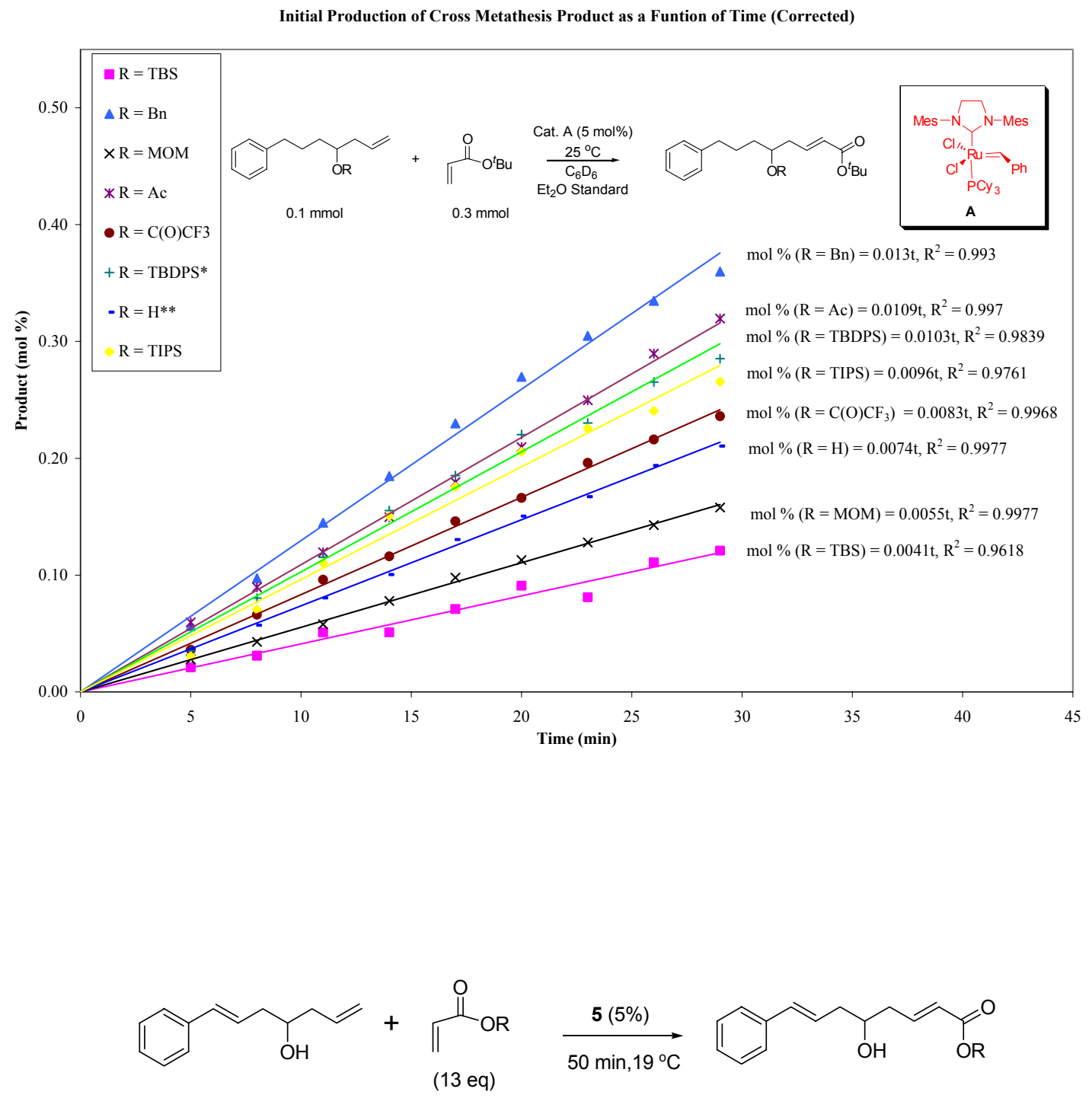

\begin{tabular}{ccc}
\hline Entry & $\mathrm{R}$ & Yield (no. \%) \\
\hline 1 & $\mathrm{Me}$ & $\mathbf{3 4 7 3}$ \\
2 & $\mathrm{Et}$ & $\mathbf{S u p 1 2 5 0}$ \\
3 & $n \mathrm{Bu}$ & Sup13 51 \\
4 & ${ }^{t} \mathrm{Bu}$ & $\mathbf{3 5} 64$
\end{tabular}

All reactions performed on $\sim 0.5 \mathrm{mmol}$ scale. ${ }^{\mathrm{a}}$ Isolated yield.

SupTable 2. Effect of Acrylate Metathesis Partner (optimized conditions). 
<smiles>COC(=O)/C=C/CC(O)C/C=C/c1ccccc1</smiles>

(34): (+/-)-Methyl (2E,7E)-5-hydroxy-8-phenylocta-2,7-dienoate (General and Optimized Procedure)

A $10 \mathrm{~mL}$ round bottom flask was touched under a stream of nitrogen and allowed to cool to room temperature. It was then charged with $7(100 \mathrm{mg}, 0.53 \mathrm{mmol})$ and methyl acrylate $(620 \mu \mathrm{L}, 6.84 \mathrm{mmol})$ and Grubbs' second generation catalyst (5) was added as a solid $(22.5 \mathrm{mg}, 0.027 \mathrm{mmol})$ to the flask maintained at $19+/-1^{\circ} \mathrm{C}$. The reaction was followed carefully by TLC and when the starting material had nearly been consumed (50 minutes) the reaction mixture was loaded directly upon a wet column packed with silica gel and purified by flash chromatography $(17 \%$ EtOAc/Hex) to afford the product as a colorless oil (yield = 73\%). $\mathrm{R}_{f}=0.18(17 \%$ EtOAc/Hex $) ;{ }^{1} \mathrm{H} \mathrm{NMR}\left(400 \mathrm{MHz}, \mathrm{CDCl}_{3}\right) \delta$ $7.38-7.27$ (m, 4H), $7.25-7.19$ (m, 1H), 7.02 (ddd, $J=15.6 \mathrm{~Hz}, 7.2 \mathrm{~Hz}, 7.2 \mathrm{~Hz}, 1 \mathrm{H})$, 6.49 (d, $J=15.6 \mathrm{~Hz}, 1 \mathrm{H}), 6.20$ (ddd, $J=15.6 \mathrm{~Hz}, 7.6 \mathrm{~Hz}, 7.6 \mathrm{~Hz}, 1 \mathrm{H}), 5.93$ (d, $J=15.6$ $\mathrm{Hz}, 1 \mathrm{H}), 3.93-3.85(\mathrm{~m}, 1 \mathrm{H}), 3.73(\mathrm{~s}, 3 \mathrm{H}), 2.50-2.30(\mathrm{~m}, 4 \mathrm{H}), 1.98-1.92(\mathrm{~m}, 1 \mathrm{H}) ;{ }^{13} \mathrm{C}$ NMR $\left(100 \mathrm{MHz}, \mathrm{CDCl}_{3}\right) \delta 167.0,195.5,137.2,133.9,128.8,127.6,126.3,125.6,123.7$, 70.0, 51.7, 41.0, 39.7; FTIR (neat) ט 3431, 2948, 2917, 1720, 1661, 1439, 1328, 1277 , $1211,1041,970 \mathrm{~cm}^{-1}$; HRMS $(\mathrm{m} / z)$ calculated for $\mathrm{C}_{15} \mathrm{H}_{18} \mathrm{O}_{3} 246.1256$, found 246.1262.<smiles>CCOC(=O)/C=C/CC(O)C/C=C/c1ccccc1</smiles>

\section{(Sup12): (+/-)-Ethyl (2E,7E)-5-hydroxy-8-phenylocta-2,7-dienoate}

Prepared following the cross metathesis protocol outlined for $\mathbf{3 4}$ with ethyl acrylate $(744 \mu \mathrm{L}, 6.84 \mathrm{mmol})$ in place of methyl acrylate and a reaction time of 50 minutes. The crude reaction mixture was purified by flash chromatography (10 to $17 \%$ EtOAc/Hex) to afford the product as a colorless oil (yield $=50 \%) . \quad \mathrm{R}_{f}=0.20(10 \%$ EtOAc/Hex); ${ }^{1} \mathrm{H}$ NMR (400 MHz, $\left.\mathrm{CDCl}_{3}\right) \delta 7.38-7.33(\mathrm{~m}, 2 \mathrm{H}), 7.33-7.27(\mathrm{~m}, 2 \mathrm{H})$, $7.25-7.20(\mathrm{~m}, 1 \mathrm{H}), 7.01$ (ddd, $J=15.6 \mathrm{~Hz}, 7.6 \mathrm{~Hz}, 7.6 \mathrm{~Hz}, 1 \mathrm{H}), 6.49$ (d, $J=15.6 \mathrm{~Hz}$, $1 \mathrm{H}), 6.21(\mathrm{ddd}, J=15.6 \mathrm{~Hz}, 7.6 \mathrm{~Hz}, 7.6 \mathrm{~Hz}, 1 \mathrm{H}), 5.92(\mathrm{~d}, J=15.6 \mathrm{~Hz}, 1 \mathrm{H}), 4.19(\mathrm{q}, J=$ $7.2 \mathrm{~Hz}, 2 \mathrm{H}), 3.93-3.84(\mathrm{~m}, 1 \mathrm{H}), 2.50-2.32(\mathrm{~m}, 4 \mathrm{H}), 2.04(\mathrm{~d}, J=3.6 \mathrm{~Hz}, 1 \mathrm{H}), 1.29$ (t, $J$ $=7.2 \mathrm{~Hz}, 3 \mathrm{H}) ;{ }^{13} \mathrm{C} \mathrm{NMR}\left(100 \mathrm{MHz}, \mathrm{CDCl}_{3}\right) \delta 166.6,145.2,137.2,133.8,128.8,127.7$, 126.4, 125.7, 124.2, 70.1, 60.6, 41.0, 39.8, 14.5; FTIR (neat) v 3435, 2981, 2932, 1716, $1652,1368,1271,1187,1043,969 \mathrm{~cm}^{-1}$; $\operatorname{HRMS}(\mathrm{m} / \mathrm{z})$ calculated for $\mathrm{C}_{16} \mathrm{H}_{20} \mathrm{O}_{3} 260.1412$, found 260.1402 .<smiles>CCCOC(=O)/C=C/CC(O)C/C=C/c1ccccc1</smiles>

(Sup13): (+/-)-Butyl (2E,7E)-5-hydroxy-8-phenylocta-2,7-dienoate

Prepared following the cross metathesis protocol outlined for $\mathbf{3 4}$ with butyl acrylate $(980 \mu \mathrm{L}, 6.84 \mathrm{mmol})$ in place of methyl acrylate and a reaction time of 50 minutes. The crude reaction mixture was purified by flash chromatography $(10 \%$ EtOAc/Hex) to afford the product as a colorless oil (yield $=51 \%) . \quad \mathrm{R}_{f}=0.29(17 \%$ 
EtOAc/Hex); ${ }^{1} \mathrm{H}$ NMR (400 MHz, $\left.\mathrm{CDCl}_{3}\right) \delta 7.38-7.28(\mathrm{~m}, 4 \mathrm{H}), 7.25-7.20(\mathrm{~m}, 1 \mathrm{H})$, 7.00 (ddd, $J=15.6 \mathrm{~Hz}, 7.2 \mathrm{~Hz}, 7.2 \mathrm{~Hz}, 1 \mathrm{H}), 6.49$ (d, $J=16.0 \mathrm{~Hz}, 1 \mathrm{H}), 6.21$ (ddd, $J=$ $16.0 \mathrm{~Hz}, 7.2 \mathrm{~Hz}, 7.2 \mathrm{~Hz}, 1 \mathrm{H}), 5.93(\mathrm{~d}, J=15.6 \mathrm{~Hz}, 1 \mathrm{H}), 4.14(\mathrm{t}, J=6.8 \mathrm{~Hz}, 2 \mathrm{H}), 3.94-$ $3.85(\mathrm{~m}, 1 \mathrm{H}), 2.50-2.32(\mathrm{~m}, 4 \mathrm{H}), 1.97(\mathrm{~d}, J=4.0 \mathrm{~Hz}, 1 \mathrm{H}), 1.69-1.59(\mathrm{~m}, 2 \mathrm{H}), 1.45-$ $1.34(\mathrm{~m}, 2 \mathrm{H}), 0.94(\mathrm{t}, J=7.6 \mathrm{~Hz}, 3 \mathrm{H}) ;{ }^{13} \mathrm{C} \mathrm{NMR}\left(100 \mathrm{MHz}, \mathrm{CDCl}_{3}\right) \delta 166.7,145.1$, $137.3,133.9,128.8,127.7,126.4,125.7,124.2$, 70.1, 64.5, 41.0, 39.8, 30.9, 19.4, 14.0; FTIR (neat) v 3428, 2959, 1716, 1655, 1322, 1274, 1186, 1063, $968 \mathrm{~cm}^{-1}$; HRMS $(\mathrm{m} / \mathrm{z})$ calculated for $\mathrm{C}_{18} \mathrm{H}_{24} \mathrm{O}_{3} 288.1725$, found 288.1729.<smiles>CCCOC(=O)C=CCC(O)CC=Cc1ccccc1</smiles>

\section{(35): (+/-)-tert-Butyl (2E,7E)-5-hydroxy-8-phenylocta-2,7-dienoate}

Prepared following the cross metathesis protocol outlined for $\mathbf{3 4}$ with $t$-butyl acrylate $(1.0 \mathrm{~mL}, 6.84 \mathrm{mmol})$ in place of methyl acrylate and a reaction time of 50 minutes. The crude reaction mixture was purified by flash chromatography (10 to $12.5 \%$ EtOAc/Hex) to afford the product as a colorless oil (yield $=64 \%) . \quad \mathrm{R}_{f}=0.45(25 \%$ EtOAc/Hex); ${ }^{1} \mathrm{H}$ NMR (400 MHz, $\left.\mathrm{CDCl}_{3}\right) \delta 7.29-7.37(\mathrm{~m}, 4 \mathrm{H}), 7.20-7.24(\mathrm{~m}, 1 \mathrm{H})$, 6.89 (ddd, $J=15.6 \mathrm{~Hz}, 7.6 \mathrm{~Hz}, 7.6 \mathrm{~Hz}, 1 \mathrm{H}), 6.50$ (d, $J=16.0 \mathrm{~Hz}, 1 \mathrm{H}), 6.21$ (ddd, $J=$ $16.0 \mathrm{~Hz}, 7.6 \mathrm{~Hz}, 7.6 \mathrm{~Hz}, 1 \mathrm{H}), 5.85$ (d, $J=15.6 \mathrm{~Hz}, 1 \mathrm{H}), 3.93-3.84(\mathrm{~m}, 1 \mathrm{H}), 2.23-2.25$ $(\mathrm{m}, 4 \mathrm{H}), 1.86$ (brs, $1 \mathrm{H}), 1.49$ (s, 9H); ${ }^{13} \mathrm{C} \mathrm{NMR}\left(100 \mathrm{MHz}, \mathrm{CDCl}_{3}\right) \delta 165.9,143.7,137.3$, 133.8, 128.8, 127.6, 126.3, 126.0, 125.7, 80.5, 70.1, 40.9, 39.6, 28.3; FTIR (neat) u 3419, 3028, 2979, 2932, 1713, 1653, 1367, 1326, 1153, 980, 970, 850, 746, $692 \mathrm{~cm}^{-1}$; HRMS $(\mathrm{m} / z)$ calculated for $\mathrm{C}_{14} \mathrm{H}_{16} \mathrm{O}_{3}\left(\mathrm{M}-\mathrm{C}_{4} \mathrm{H}_{9}\right)^{+} 232.1099$, found 232.1106 .

For the Preparation of $\mathbf{2 3}$

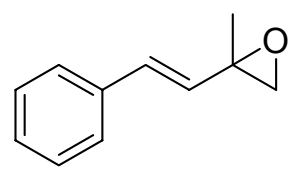

(Sup14): (+/-)-2-Methyl-2-[(E)-2-phenylvinyl]oxirane

A $100 \mathrm{~mL}$ round bottom flask was charged with (3E)-4-phenylbuten-2-one $(3.0 \mathrm{~g}$, $20.5 \mathrm{mmol})$, trimethylsulfonium methyl sulfate $(4.6 \mathrm{~g}, 24.4 \mathrm{mmol})$ and benzyltriethylammonium chloride $(103 \mathrm{mg}, 0.45 \mathrm{mmol})$. Dichloromethane $(21 \mathrm{~mL})$ was added followed by $50 \%(\mathrm{w} / \mathrm{v}) \mathrm{NaOH}_{\mathrm{aq}}(10.2 \mathrm{~mL})$. A reflux condenser was attached and the stirring biphasic mixture heated to $50{ }^{\circ} \mathrm{C}$ for 16 hours. The heating bath was removed and the flask was allowed to cool to room temperature. Ether and water were added and the reaction mixture transferred to a separatory funnel. The organic layer was isolated, the aqueous layer back extracted with ether, the organics combined, dried with magnesium sulfate and the solvent removed in vacuo. The product was recovered as a orange viscous oil (yield $=91 \%$ ) of fairly good purity $(>95 \%)$. The product may be purified by flash chromatography $\left(5 \% \mathrm{Et}_{3} \mathrm{~N}, 8 \mathrm{Hex}: 2 \mathrm{EtOAc}\right)($ yield $=20 \%) ; \mathrm{R}_{f}=0.71$ $\left(5 \% \mathrm{Et}_{3} \mathrm{~N}, 8 \mathrm{Hex}: 2 \mathrm{EtOAc}\right)$. This compound yielded spectra data consistent with literature reports, see for example: Latuens, M.; Maddess, M. L.; Effiette, L. O. S.; Ouellet, S. G. Org. Lett. 2002, 4, 83. 
<smiles>C=CCC(O)C(C)/C=C/c1ccccc1</smiles>

(23): (+/-)-(1E)-3-Methyl-1-phenylhepta-1,6-dien-4-ol ( $\mathrm{dr}=1.2$ : 1$)$

Prepared following the allylation protocol outlined for 7 with Sup14 (1.38 g, 8.61 $\mathrm{mmol}$ ) and a reaction time of 90 minutes at room temperature. The crude residue was purified by flash chromatography (10 to $17 \%$ EtOAc/Hex) to afford the product as an inseparable mixture of diastereomers $\left(\mathrm{dr}=1.2: 1,{ }^{1} \mathrm{H} \mathrm{NMR}\right)$ recovered as a white solid (yield $=70 \%) . \mathrm{R}_{f}=0.49\left(10 \% \mathrm{EtOAc} / \mathrm{PhCH}_{3}\right)$. This compound yielded spectra data consistent with literature reports, see for example: Latuens, M.; Maddess, M. L.; Effiette, L. O. S.; Ouellet, S. G. Org. Lett. 2002, 4, 83.<smiles>CCCOC(=O)/C=C/CC(O)C(C)/C=C/c1ccccc1</smiles>

(36): (+/-)-tert-Butyl (2E,7E)-5-hydroxy-6-methyl-8-phenylocta-2,7-dienoate $(\mathrm{dr}=$ $1.2: 1)$

Prepared following the cross metathesis protocol outlined for $\mathbf{3 4}$ with $\mathbf{2 3}$ (100 $\mathrm{mg}$, $0.49 \mathrm{mmol}), t$-butyl acrylate $(1.0 \mathrm{~mL}, 6.84 \mathrm{mmol})$ in place of methyl acrylate and a reaction time of 50 minutes. The crude reaction mixture was purified by flash chromatography $(10 \%$ EtOAc/Hex) to afford the product as an inseparable mixture of diastereomers $(\mathrm{dr}=1.2: 1, \mathrm{HPLC})$ recovered as a colorless oil (yield $=60 \%) . \quad \mathrm{R}_{f}=0.32$ $(17 \%$ EtOAc/Hex $) ;{ }^{1} \mathrm{H}$ NMR $\left(400 \mathrm{MHz}, \mathrm{CDCl}_{3}\right) \delta 7.38-7.19(\mathrm{~m}, 10 \mathrm{H}), 6.96-6.84(\mathrm{~m}$, $2 \mathrm{H}), 6.50-6.40(\mathrm{~m}, 2 \mathrm{H}), 6.19-6.09(\mathrm{~m}, 2 \mathrm{H}), 5.88-5.79(\mathrm{~m}, 2 \mathrm{H}), 6.18-6.10(\mathrm{~m}, 2 \mathrm{H})$, $5.87-5.80(\mathrm{~m}, 2 \mathrm{H}), 3.72-3.60(\mathrm{~m}, 2 \mathrm{H}), 2.50-2.24(\mathrm{~m}, 6 \mathrm{H}), 2.02-1.90(\mathrm{~m}, 2 \mathrm{H}), 1.48$ - $1.46(\mathrm{~m}, 18 \mathrm{H}), 1.17-1.12(\mathrm{~m}, 6 \mathrm{H}) ;{ }^{13} \mathrm{C} \mathrm{NMR}\left(100 \mathrm{MHz}, \mathrm{CDCl}_{3}\right) \delta 166.0,165.9$, $144.5,144.3,137.4,137.3,132.1,132.0,131.2,131.0,128.7,127.5,127.4,126.3,126.3$, $125.7,125.6,80.4,80.4,74.1,74.0,43.4,43.2,37.5,37.4,28.3,17.0,15.6$; FTIR (neat) $v$ $3435,2977,2933,1713,1694,1367,1154,972,748 \mathrm{~cm}^{-1}$; HRMS $(\mathrm{m} / z)$ calculated for $\mathrm{C}_{15} \mathrm{H}_{18} \mathrm{O}_{3}\left(\mathrm{M}-\mathrm{C}_{4} \mathrm{H}_{9}\right)^{+} 246.1256$, found 246.1252.

For the Preparation of $\mathbf{2 4}$

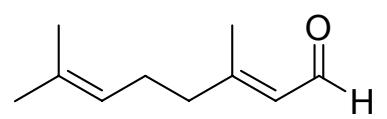

\section{(Sup15): (2E)-3,7-Dimethylocta-2,6-dienal}

A dry $250 \mathrm{~mL}$ round bottom flask was charged with Geraniol $(6.0 \mathrm{~mL}, 34.5$ mmol) and DCM $(30 \mathrm{~mL})$. To the resulting solution was added $\mathrm{MnO}_{2}(30 \mathrm{~g}, 345 \mathrm{mmol})$ and the mixture left stirring for 14 hours. The reaction contents were then filtered through a pad of celite with additional DCM and the solvent removed in vacuo. The crude product was purified by flash chromatography $(10 \%$ EtOAc/Hex $)$ to afford the product as a colorless oil (yield $=76 \%) . \mathrm{R}_{f}=0.59(17 \%$ EtOAc/Hex). This compound yielded spectra data consistent with literature reports, see for example: Picquet, M.; Fernadez, A; Bruneau, C.; Dixneuf, P. H. Eur. J. Org. Chem. 2000, 13, 2361. 


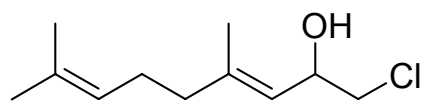

(Sup16): (+/-)-(3E)-1-Chloro-4,8-dimethylnona-3,7-dien-2-ol

Prepared following the addition protocol outlined for Sup1 with Sup15 (3.87 g, $25.4 \mathrm{mmol}$ ) in place of trans-cinnamaldehyde and a reaction time of 10 minutes post $n \mathrm{BuLi}$ addition. The crude reaction mixture was purified by flash chromatography $(10 \%$ EtOAc/Hex) to afford the product as a colorless oil (yield $=86 \%) . \quad \mathrm{R}_{f}=0.51(17 \%$ EtOAc/Hex); ${ }^{1} \mathrm{H}$ NMR $\left(300 \mathrm{MHz}, \mathrm{CDCl}_{3}\right) \delta 5.19$ (dq, $\left.J=8.1 \mathrm{~Hz}, 1.2 \mathrm{~Hz}, 1 \mathrm{H}\right), 5.11-$ $5.02(\mathrm{~m}, 1 \mathrm{H}), 4.57$ (dddd, $J=8.1 \mathrm{~Hz}, 7.8 \mathrm{~Hz}, 3.9 \mathrm{~Hz}, 3.6 \mathrm{~Hz}, 1 \mathrm{H}), 3.55$ (dd, $J=11.1 \mathrm{~Hz}$, $3.9 \mathrm{~Hz}, 1 \mathrm{H}), 3.48$ (dd, $J=11.1 \mathrm{~Hz}, 7.8 \mathrm{~Hz}, 1 \mathrm{H}), 2.20$ (d, $J=3.6 \mathrm{~Hz}, 1 \mathrm{H}), 2.16-2.00$ (m, $4 \mathrm{H}), 1.72(\mathrm{~d}, J=1.2 \mathrm{~Hz}, 3 \mathrm{H}), 1.68(\mathrm{~s}, 3 \mathrm{H}), 1.60(\mathrm{~s}, 3 \mathrm{H}) ;{ }^{13} \mathrm{C} \mathrm{NMR}\left(75 \mathrm{MHz}, \mathrm{CDCl}_{3}\right) \delta$ 142.1, 132.2, 123.9, 123.1, 69.1, 50.0, 39.7, 26.5, 26.0, 18.0, 17.2; FTIR (neat) v 3384, 2969, 2925, 2858, 1669, 1437, 1381, 1248, 1061, 839, $731 \mathrm{~cm}^{-1}$; EI-MS $(\mathrm{m} / z) 202(\mathrm{M})^{+}$.

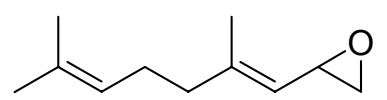

(Sup17): (+/-)-2-[(1E)-2,6-Dimethylhepta-1,5-dienyl]oxirane

Prepared following the ring closure protocol outlined for Sup2 with Sup16 (2.52 $\mathrm{g}, 12.4 \mathrm{mmol}$ ) in place of Sup1 and a reaction time of 75 minutes. The crude residue was dried under high vacuum to afford the product as a light yellow oil in good purity $(>95 \%)$ (yield = 94\%). ${ }^{1} \mathrm{H} \mathrm{NMR}\left(300 \mathrm{MHz}, \mathrm{CDCl}_{3}\right) \delta 5.12-5.02(\mathrm{~m}, 1 \mathrm{H}), 4.82(\mathrm{dq}, J=8.7 \mathrm{~Hz}$, $1.2 \mathrm{~Hz}, 1 \mathrm{H}$ ), 3.57 (ddd, $J=8.7 \mathrm{~Hz}, 4.2 \mathrm{~Hz}, 3.0 \mathrm{~Hz}, 1 \mathrm{H}$ ), 2.98 (dd, $J=5.1 \mathrm{~Hz}, 4.2 \mathrm{~Hz}$, $1 \mathrm{H}), 2.65(\mathrm{dd}, J=5.1 \mathrm{~Hz}, 3.0 \mathrm{~Hz}, 1 \mathrm{H}), 2.14-2.01(\mathrm{~m}, 4 \mathrm{H}), 1.82(\mathrm{~d}, J=1.2 \mathrm{~Hz}, 3 \mathrm{H})$, $1.68(\mathrm{~s}, 3 \mathrm{H}), 1.60(\mathrm{~s}, 3 \mathrm{H}) ;{ }^{13} \mathrm{C} \mathrm{NMR}\left(75 \mathrm{MHz}, \mathrm{CDCl}_{3}\right) \delta=144.3,132.2,123.9,122.2$, 49.3, 49.3, 39.9, 26.5, 26.0, 18.0, 17.0; FTIR (neat) ৩ 2915, 2729, 1670, 1447, 1377 , $1251,1208,1133,1106,1045,984,938,835,773 \mathrm{~cm}^{-1}$; EI-MS $(\mathrm{m} / z) 166(\mathrm{M})^{+}$.

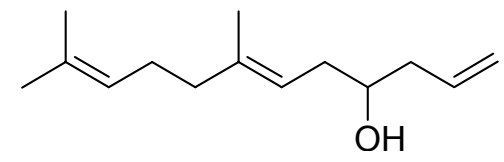

\section{(24): (+/-)-(6E)-7,11-Dimethyldodeca-1,6,10-trien-4-ol}

Prepared following the allylation protocol outlined for 7 with Sup17 (300 mg, $1.80 \mathrm{mmol}$ ) and a reaction time of 2 hours. The crude residue was purified by flash chromatography $\left(15 \% \mathrm{Et}_{2} \mathrm{O} / \mathrm{Hex}\right)$ to afford the product as a colorless oil (yield $=60 \%$ ). $\mathrm{R}_{f}=0.29\left(15 \% \mathrm{Et}_{2} \mathrm{O} / \mathrm{Hex}\right) ;{ }^{1} \mathrm{H}$ NMR $\left(300 \mathrm{MHz}, \mathrm{CDCl}_{3}\right) \delta 5.91-5.78(\mathrm{~m}, 1 \mathrm{H}), 5.21-$ $5.03(\mathrm{~m}, 4 \mathrm{H}), 3.70-3.61(\mathrm{~m}, 1 \mathrm{H}), 2.33-2.24(\mathrm{~m}, 1 \mathrm{H}), 2.22-2.14(\mathrm{~m}, 3 \mathrm{H}), 2.12-2.01$ $(\mathrm{m}, .4 \mathrm{H}), 1.81$ (brs, 1H), $1.68(\mathrm{~s}, 3 \mathrm{H}), 1.63(\mathrm{~s}, 3 \mathrm{H}), 1.60(\mathrm{~s}, 3 \mathrm{H}) ;{ }^{13} \mathrm{C}$ NMR $(75 \mathrm{MHz}$, $\left.\mathrm{CDCl}_{3}\right) \delta 139.1,135.3,132.0,124.4,120.1,118.0,70.9,41.4,40.1,35.7,26.8,26.0,17.9$, 16.5 ; FTIR (neat) $\mathrm{3} 364,3078,2967,2915,1641,1435,1376,1048,995,913 \mathrm{~cm}^{-1}$; HRMS $(\mathrm{m} / z)$ calculated for $\mathrm{C}_{14} \mathrm{H}_{24} \mathrm{O} 208.1827$, found 208.1816 . 


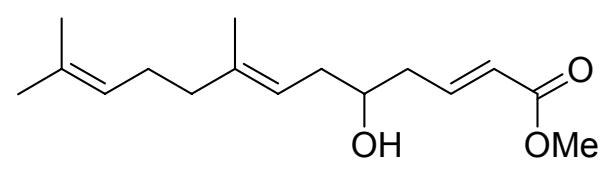

(37): (+/-)-Methyl (2E,7E)-5-hydroxy-8,12-dimethyltrideca-2,7,11-trienoate

Prepared following the cross metathesis protocol outlined for $\mathbf{3 4}$ with $\mathbf{2 4}$ (100 mg, $0.48 \mathrm{mmol}$ ) and a reaction time of 50 minutes. The crude reaction mixture was purified by flash chromatography $\left(30 \% \mathrm{Et}_{2} \mathrm{O} / \mathrm{Hex}\right)$ to afford the product as a colorless oil (yield $=$ $68 \%) . \quad \mathrm{R}_{f}=0.51(25 \% \mathrm{EtOAc} / \mathrm{Hex}) ;{ }^{1} \mathrm{H} \mathrm{NMR}\left(400 \mathrm{MHz}, \mathrm{CDCl}_{3}\right) \delta 6.98$ (ddd, $J=15.6$ $\mathrm{Hz}, 7.2 \mathrm{~Hz}, 7.2 \mathrm{~Hz}, 1 \mathrm{H}), 5.88(\mathrm{~d}, J=15.6 \mathrm{~Hz}, 1 \mathrm{H}), 5.15-5.00(\mathrm{~m}, 2 \mathrm{H}), 3.76-3.69$ (m, $1 \mathrm{H}), 3.70(\mathrm{~s}, 3 \mathrm{H}), 2.42-2.28(\mathrm{~m}, 2 \mathrm{H}), 2.21-2.16(\mathrm{~m}, 2 \mathrm{H}), 2.10-2.00(\mathrm{~m}, 4 \mathrm{H}), 1.95$ (brs, 1H), $1.65(\mathrm{~s}, 3 \mathrm{H}), 1.60(\mathrm{~s}, 3 \mathrm{H}), 1.58(\mathrm{~s}, 3 \mathrm{H}) ;{ }^{13} \mathrm{C} \mathrm{NMR}\left(100 \mathrm{MHz}, \mathrm{CDCl}_{3}\right) \delta 167.0$, $146.0,139.6,132.0,124.3,123.4,119.5,70.5,51.7,40.0,39.5,35.9,26.6,25.9,17.9$, 16.5, 17.9, 16.5; FTIR (neat) ৩ 3446, 2916, 1726, 1658, 1436, 1271, 1211, $1174 \mathrm{~cm}^{-1}$; HRMS $(m / z)$ calculated for $\mathrm{C}_{16} \mathrm{H}_{26} \mathrm{O}_{3} 266.1882$, found 266.1881 .

For the Preparation of $\mathbf{2 5}$<smiles>COc1ccc(/C=C/C(O)CCl)cc1</smiles>

(Sup18): (+/-)-(3E)-1-Chloro-4-(4-methoxyphenyl)but-3-en-2-ol

Prepared following the addition protocol outlined for Sup1 with 4-methoxy-transcinnamaldehyde $(1.0 \mathrm{~g}, 6.16 \mathrm{mmol})$ in place of trans-cinnamaldehyde and a reaction time of 60 minutes post $n \mathrm{BuLi}$ addition. The crude reaction mixture was purified by flash chromatography $(12.5$ to $17 \% \mathrm{EtOAc} / \mathrm{Hex})$ to afford the product as a light yellow solid (yield $=81 \%) . \mathrm{R}_{f}=0.51(25 \%$ EtOAc/Hex $)$; melting point $=64{ }^{\circ} \mathrm{C} ;{ }^{1} \mathrm{H}$ NMR $(300 \mathrm{MHz}$, $\left.\mathrm{CDCl}_{3}\right) \delta 7.38-7.33(\mathrm{~m}, 2 \mathrm{H}), 6.92-6.86(\mathrm{~m}, 2 \mathrm{H}), 6.69(\mathrm{~d}, J=15.9 \mathrm{~Hz}, 1 \mathrm{H}), 6.08(\mathrm{dd}, J$ $=15.9 \mathrm{~Hz}, 6.3 \mathrm{~Hz}, 1 \mathrm{H}), 4.43-4.60(\mathrm{~m}, 1 \mathrm{H}), 3.84(\mathrm{~s}, 3 \mathrm{H}), 3.73(\mathrm{dd}, J=11.1 \mathrm{~Hz}, 3.9 \mathrm{~Hz}$, $1 \mathrm{H}), 3.61(\mathrm{dd}, J=11.1 \mathrm{~Hz}, 7.5 \mathrm{~Hz}, 1 \mathrm{H}), 2.39(\mathrm{~d}, J=3.9 \mathrm{~Hz}, 1 \mathrm{H}) ;{ }^{13} \mathrm{C}$ NMR $(75 \mathrm{MHz}$, $\left.\mathrm{CDCl}_{3}\right) \delta 159.9,132.7,129.0,128.2,125.1,114.3,72.8,55.6,51.1$; FTIR (neat) $\cup ~ 3387$, 2953, 1605, 1513, 1250, 1176, 1033, 959, $815 \mathrm{~cm}^{-1}$; HRMS $(\mathrm{m} / z)$ calculated for $\mathrm{C}_{11} \mathrm{H}_{13} \mathrm{ClO}_{2} 212.0604$, found 212.0607 .<smiles>C=CC[C@H](O)C/C=C/c1ccc(OC)cc1</smiles>

\section{(25): (1E,4S)-1-(4-Methoxyphenyl)hepta-1,6-dien-4-ol}

A $25 \mathrm{~mL}$ round bottom flask was touched under a stream of nitrogen and allowed to cool to room temperature. It was then charged with THF $(3 \mathrm{~mL})$ and cooled to $0{ }^{\circ} \mathrm{C}$. To this was added $\mathrm{NaH}(95 \%, 50 \mathrm{mg}, 1.94 \mathrm{mmol}), \mathrm{NaI}(18.7 \mathrm{mg}, 0.13 \mathrm{mmol})$ and Sup18 $(275 \mathrm{mg}, 1.29 \mathrm{mmol})$ was added dropwise as a solution in THF $(1+0.5 \mathrm{~mL})$. The reaction was left stirring for 90 minutes at $0{ }^{\circ} \mathrm{C}$ and then cooled to $-78{ }^{\circ} \mathrm{C}$. (+)- 
Ipc $_{2} \mathrm{BAllyl}^{*}(0.77 \mathrm{M}$ in THF, $3.9 \mathrm{~mL}, 3.00 \mathrm{mmol})$ was added via syringe followed by the addition of $\mathrm{Sc}(\mathrm{OTf})_{3}(48 \mathrm{mg}, 0.10 \mathrm{mmol})$ also as a solution in THF $(1 \mathrm{~mL})$. The resulting mixture was stirred for 6 hours at $-78{ }^{\circ} \mathrm{C}$ and then $3 \mathrm{~N} \mathrm{NaOH}(1.8 \mathrm{~mL})$ and $30 \% \mathrm{H}_{2} \mathrm{O}_{2}$ $(1.8 \mathrm{~mL})$ were added sequentially. The reaction vessel was warmed to room temperature and stirred for 14 hours and then the contents were transferred to a separatory funnel with $\mathrm{NH}_{4} \mathrm{Cl}_{\mathrm{aq}}$ and ether. The organic layer was isolated, the aqueous layer extracted with ether, and the combined organics dried with $\mathrm{MgSO}_{4}$, filtered and concentrated in vacuo. The crude residue was purified by successive flash chromatography (2 x 5\% EtOAc $/ \mathrm{PhCH}_{3}$, then $10 \% \mathrm{EtOAc} / \mathrm{Hex}$ ) to afford the product as a colorless oil (yield = $53 \%) . \mathrm{R}_{f}=0.39\left(10 \% \mathrm{EtOAc} / \mathrm{PhCH}_{3}\right) ;{ }^{1} \mathrm{H} \mathrm{NMR}\left(400 \mathrm{MHz}, \mathrm{CDCl}_{3}\right) \delta 7.31-7.28(\mathrm{~m}$, 2H), $6.86-6.83(\mathrm{~m}, 2 \mathrm{H}), 6.43(\mathrm{~d}, J=16 \mathrm{~Hz}, 1 \mathrm{H}), 6.09$ (ddd, $J=16.0 \mathrm{~Hz}, 7.4 \mathrm{~Hz}, 7.4 \mathrm{~Hz}$, $1 \mathrm{H}), 5.92-5.91(\mathrm{~m}, 1 \mathrm{H}), 5.19-5.13(\mathrm{~m}, 2 \mathrm{H}), 3.80(\mathrm{~s}, 3 \mathrm{H}), 3.81-3.74(\mathrm{~m}, 1 \mathrm{H}), 2.47-$ $2.20(\mathrm{~m}, 4 \mathrm{H}), 1.80(\mathrm{~d}, J=3.6 \mathrm{~Hz}, 1 \mathrm{H}) ;{ }^{13} \mathrm{C} \mathrm{NMR}\left(100 \mathrm{MHz}, \mathrm{CDCl}_{3}\right) \delta 159.2,134.9$, $1132.8,130.3,127.5,124.3,118.3,114.2,70.5,55.5,41.5,40.7$; FTIR (neat) v $3392,2930,2836,1608,1511,1461,1248,1176,1034,969,916,836 \mathrm{~cm}^{-1}$; $\quad$ HRMS $(\mathrm{m} / \mathrm{z})$ calculated for $\mathrm{C}_{14} \mathrm{H}_{18} \mathrm{O}_{2}$ 218.1307, found 218.1312. HPLC (CHIRALCEL OD, 1 $\mathrm{mL} / \mathrm{min}, 95 \mathrm{Hex}: 5 i \mathrm{~Pa}, 30{ }^{\circ} \mathrm{C}, 1 \mu \mathrm{L}$ injection) $\mathrm{RT}_{1}=12.1 \mathrm{~min}, \mathrm{RT}_{2}=14.7 \mathrm{~min}$; ee** $=$ $95 \% ;[\alpha]^{20}=+10.0^{\circ}\left(\mathrm{c}=1.0, \mathrm{CHCl}_{3}\right)$.

* For preparation reference see the supplementary material of Lautens, M.; Maddess, M. L.; Effiette, L. O. S.; Ouellet, S. G. Org. Lett. 2002, 4, 83 (modified procedure from that of Racherla, U. S.; Brown, H. C. J. Org. Chem. 1991, 56, 401).

** HPLC retention times confirmed by preparation of $(1 E, 4 R)-1-(4-$ Methoxyphenyl)hepta-1,6-dien-4-ol using (-)-Ipc 2 BAllyl.<smiles>COC(=O)/C=C/C[C@H](O)C/C=C/c1ccc(OC)cc1</smiles>

\section{(38): Methyl (2E,5R,7E)-5-hydroxy-8-(4-methoxyphenyl)octa-2,7-dienoate}

Prepared following the cross metathesis protocol outlined for $\mathbf{3 4}$ with $\mathbf{2 5}$ (90 mg, $0.42 \mathrm{mmol}$ ) and a reaction time of 50 minutes. The crude reaction mixture was purified by flash chromatography (17 to $33 \% \mathrm{EtOAc} / \mathrm{Hex}$ ) to afford the product as a yellow oil $($ yield $=43 \%) . \quad \mathrm{R}_{f}=0.39(33 \% \mathrm{EtOAc} / \mathrm{Hex}) ;{ }^{1} \mathrm{H} \mathrm{NMR}\left(400 \mathrm{MHz}, \mathrm{CDCl}_{3}\right) \delta 7.32-7.28$ (m, 2H), 7.02 (ddd, $J=16.0 \mathrm{~Hz}, 7.2 \mathrm{~Hz}, 7.2 \mathrm{~Hz}, 1 \mathrm{H}), 6.87-6.83$ (m, 2H), 6.44 (d, $J=$ $16.0 \mathrm{~Hz}, 1 \mathrm{H}), 6.05$ (ddd, $J=16.0 \mathrm{~Hz}, 7.2 \mathrm{~Hz}, 7.2 \mathrm{~Hz}, 1 \mathrm{H}), 5.94(\mathrm{~d}, J=16.0 \mathrm{~Hz}, 1 \mathrm{H}), 3.92$ $-3.84(\mathrm{~m}, 1 \mathrm{H}), 3.81(\mathrm{~s}, 3 \mathrm{H}), 3.74(\mathrm{~s}, 3 \mathrm{H}), 2.52-2.29(\mathrm{~m}, 4 \mathrm{H}), 1.78(\mathrm{~d}, J=3.6 \mathrm{~Hz}, 1 \mathrm{H})$;

${ }^{13} \mathrm{C}$ NMR $\left(100 \mathrm{MHz}, \mathrm{CDCl}_{3}\right) \delta 166.9,159.4,145.5,133.5,130.0,127.5,123.8,123.2$, 114.2, 70.1, 55.5, 51.7, 41.0, 39.7; FTIR (neat) ט 3427, 2949, 1719, 1511, 1248, 1175 , $1034 \mathrm{~cm}^{-1}$; HRMS $(\mathrm{m} / \mathrm{z})$ calculated for $\mathrm{C}_{16} \mathrm{H}_{20} \mathrm{O}_{4}$ 276.1362, found 276.1363. HPLC (CHIRALCEL OJ, $1 \mathrm{~mL} / \mathrm{min}, 75 \mathrm{Hex}: 25 i \mathrm{~Pa}, 30{ }^{\circ} \mathrm{C}, 1 \mu \mathrm{L}$ injection) $\mathrm{RT}_{1}=25.3 \mathrm{~min}$, $\mathrm{RT}_{2}=29.4 \mathrm{~min} ;$ ee $=94 \%$. 
For the Preparation of $\mathbf{2 6}$<smiles>O=[N+]([O-])c1ccccc1/C=C/C(O)CCl</smiles>

(Sup19): (+/-)-(3E)-1-Chloro-4-(2-nitrophenyl)but-3-en-2-ol

Prepared following the addition protocol outlined for Sup1 with 2-nitro-transcinnamaldehyde $(1.0 \mathrm{~g}, 5.64 \mathrm{mmol})$ in place of trans-cinnamaldehyde and a reaction time of 60 minutes post $n \mathrm{BuLi}$ addition. The crude reaction mixture was purified by flash chromatography $(17 \%$ EtOAc/Hex) to afford the product as a yellow viscous oil (yield = $50 \%) . \quad \mathrm{R}_{f}=0.40$ (33\% EtOAc/Hex). This compound yielded spectra data consistent with literature reports, see for example: Latuens, M.; Maddess, M. L.; Effiette, L. O. S.; Ouellet, S. G. Org. Lett. 2002, 4, 83.<smiles>O=[N+]([O-])c1ccccc1/C=C/C1CO1</smiles>

(Sup20): (+/-)-2-[(E)-2-(2-Nitrophenyl)vinyl]oxirane

Prepared following the ring closure protocol outlined for Sup2 with Sup19 (300 $\mathrm{mg}, 1.32 \mathrm{mmol}$ ) in place of Sup1 and a reaction time of 20 minutes. The crude residue was purified by flash chromatography $\left(5 \% \mathrm{Et}_{3} \mathrm{~N}, 9 \mathrm{Hex}: 1 \mathrm{EtOAc}\right)$ to afford the product as a light brown oil in good purity (yield $=87 \%) . \mathrm{R}_{f}=0.42\left(5 \% \mathrm{Et}_{3} \mathrm{~N}\right.$ in $8 \mathrm{Hex}: 2$ EtOAc). This compound yielded spectra data consistent with literature reports, see for example: Latuens, M.; Maddess, M. L.; Effiette, L. O. S.; Ouellet, S. G. Org. Lett. 2002, 4,83 .<smiles>C=CCC(O)C/C=C/c1ccccc1[N+](=O)[O-]</smiles>

\section{(26): (1E,4R)-1-(2-Nitrophenyl)hepta-1,6-dien-4-ol}

A $25 \mathrm{~mL}$ round bottom flask was flame dried under a stream of nitrogen and allowed to cool to room temperature. To this was added $\mathrm{Sc}(\mathrm{OTf})_{3}(25 \mathrm{mg}, 0.05 \mathrm{mmol})$ and THF $(4 \mathrm{~mL})$. The resulting solution was cooled to $-78{ }^{\circ} \mathrm{C}$ and (-)-Ipc $\mathrm{BAllyl}_{2}(0.77$ $\mathrm{M}$ in THF, $2.0 \mathrm{~mL}, 1.54 \mathrm{mmol})$ was added via syringe followed by the slow addition of Sup20 (130 mg, $0.68 \mathrm{mmol})$ over 1 hour as a solution in THF $(1 \mathrm{~mL})$. The reaction mixture was left for 4 hours and then transferred to a cryobath and left stirring at $-70{ }^{\circ} \mathrm{C}$ for 36 hours. $3 \mathrm{~N} \mathrm{NaOH}(1.2 \mathrm{~mL})$ and $30 \% \mathrm{H}_{2} \mathrm{O}_{2}(1.2 \mathrm{~mL})$ were then added, and the reaction vessel was warmed to room temperature and stirred for 14 hours. The reaction contents were transferred to a separatory funnel with $\mathrm{NH}_{4} \mathrm{Cl}_{\mathrm{aq}}$ and ether and the organic layer isolated. The aqueous layer was extracted with ether, the combined organics dried with $\mathrm{MgSO}_{4}$, filtered, and concentrated in vacuo. The crude residue was purified by flash chromatography (17 to 33\% EtOAc/Hex) to afford the product as a slightly yellow oil (yield $=88 \%) . \quad \mathrm{R}_{f}=0.35(33 \%$ EtOAc/Hex). HPLC (CHIRALCEL OD, $1 \mathrm{~mL} / \mathrm{min}, 97$ 
Hex : $3 i \mathrm{~Pa}, 30{ }^{\circ} \mathrm{C}, 1 \mu \mathrm{L}$ injection) $\mathrm{RT}_{1}=23.3 \mathrm{~min}, \mathrm{RT}_{2}=25.6 \mathrm{~min}$; ee** $=96 \%$. This compound yielded spectra data consistent with literature reports, see for example: Latuens, M.; Maddess, M. L.; Effiette, L. O. S.; Ouellet, S. G. Org. Lett. 2002, 4, 83.

* For preparation reference see the supplementary material of Lautens, M.; Maddess, M. L.; Effiette, L. O. S.; Ouellet, S. G. Org. Lett. 2002, 4, 83 (modified procedure from that of Racherla, U. S.; Brown, H. C. J. Org. Chem. 1991, 56, 401).

** HPLC retention times confirmed by preparation of (1E,4S)-1-(2-Nitrophenyl)hepta1,6-dien-4-ol using (+)-Ipc ${ }_{2}$ BAllyl.<smiles>COC(=O)/C=C/C[C@@H](O)C/C=C/c1ccccc1[N+](=O)[O-]</smiles>

(39): Methyl (2E,5S,7E)-5-hydroxy-8-(2-nitrophenyl)octa-2,7-dienoate

Prepared following the cross metathesis protocol outlined for $\mathbf{3 4}$ with $\mathbf{2 6}$ (130 mg, $0.56 \mathrm{mmol}$ ) and a reaction time of 50 minutes. The crude reaction mixture was purified by flash chromatography (17 to $50 \% \mathrm{EtOAc} / \mathrm{Hex}$ ) to afford the product as a yellow oil (yield $=73 \%) . \quad \mathrm{R}_{f}=0.20(33 \%$ EtOAc/Hex $) ;{ }^{1} \mathrm{H} \mathrm{NMR}\left(300 \mathrm{MHz}, \mathrm{CDCl}_{3}\right) \delta 7.92-7.87$ $(\mathrm{m}, 2 \mathrm{H}), 7.60-7.52(\mathrm{~m}, 2 \mathrm{H}), 7.41-7.34(\mathrm{~m}, 1 \mathrm{H}), 7.02(\mathrm{ddd}, J=15.9 \mathrm{~Hz}, 7.5 \mathrm{~Hz}, 7.5$ $\mathrm{Hz}, 1 \mathrm{H}), 6.92(\mathrm{~d}, J=15.9 \mathrm{~Hz}, 1 \mathrm{H}), 6.22(\mathrm{ddd}, J=15.9 \mathrm{~Hz}, 7.2 \mathrm{~Hz}, 7.2 \mathrm{~Hz}, 1 \mathrm{H}), 5.94(\mathrm{~d}, J$ $=15.9 \mathrm{~Hz}, 1 \mathrm{H}), 3.99-3.88(\mathrm{~m}, 1 \mathrm{H}), 3.72(\mathrm{~s}, 3 \mathrm{H}), 2.58-2.32(\mathrm{~m}, 5 \mathrm{H}) ;{ }^{13} \mathrm{C} \mathrm{NMR}(75$ $\left.\mathrm{MHz}, \mathrm{CDCl}_{3}\right) \delta 167.1,147.8,145.5,133.4,133.2,131.7,129.0,128.9,128.2,124.7$, 123.9, 70.0, 51.8, 40.9, 39.9; FTIR (neat) ৩ 3428, 2950, 1721, 1658, 1520, 1346, 1276, $987 \mathrm{~cm}^{-1}$; HRMS $(\mathrm{m} / z)$ calculated for $\mathrm{C}_{15} \mathrm{H}_{18} \mathrm{NO}_{5}$ 292.1185, found 292.1173. HPLC (CHIRALPAK AD, $1 \mathrm{~mL} / \mathrm{min}, 90 \mathrm{Hex}: 10 i \mathrm{~Pa}, 30{ }^{\circ} \mathrm{C}, 1 \mu \mathrm{L}$ injection) $\mathrm{RT}_{1}=23.3 \mathrm{~min}$, $\mathrm{RT}_{2}=25.5 \mathrm{~min} ;$ ee $=95 \% ;[\alpha]^{20}{ }_{\mathrm{D}}=-7.6^{\circ}\left(\mathrm{c}=1.0, \mathrm{CHCl}_{3}\right)$.

For the Preparation of $\mathbf{2 7}$<smiles>CC(=Cc1ccccc1)C(O)CCl</smiles>

\section{(Sup21): (+/-)-(3E)-1-Chloro-3-methyl-4-phenylbut-3-en-2-ol}

Prepared following the addition protocol outlined for Sup1 with $\alpha$-methyl-transcinnamaldehyde $(4.78 \mathrm{~mL}, 34.2 \mathrm{mmol})$ in place of trans-cinnamaldehyde and a reaction time of 10 minutes post $n \mathrm{BuLi}$ addition. The crude reaction mixture was purified by flash chromatography $(17 \% \mathrm{EtOAc} / \mathrm{Hex})$ to afford the product as a colorless oil (yield = $87 \%) . \mathrm{R}_{f}=0.37$ (33\% EtOAc/Hex). This compound yielded spectra data consistent with literature reports, see for example: Latuens, M.; Maddess, M. L.; Effiette, L. O. S.; Ouellet, S. G. Org. Lett. 2002, 4, 83. 


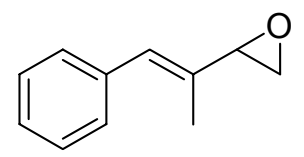

(Sup22): (+/-)-2-[(E)-1-Methyl-2-phenylvinyl]oxirane

Prepared following the ring closure protocol outlined for Sup2 with Sup21 (5.88 $\mathrm{g}, 29.9 \mathrm{mmol}$ ) in place of Sup1 and a reaction time of 60 minutes. The crude residue was dried under high vacuum to afford the product as a light yellow oil in good purity $(>95 \%)$ (yield $=97 \%) . \quad \mathrm{R}_{f}=0.66(17 \% \mathrm{EtOAc} / \mathrm{Hex})$. This compound yielded spectra data consistent with literature reports, see for example: Latuens, M.; Maddess, M. L.; Effiette, L. O. S.; Ouellet, S. G. Org. Lett. 2002, 4, 83.

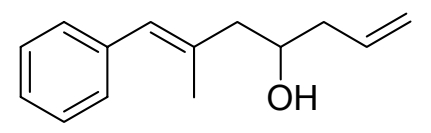

(27): (+/-)-(1E)-2-Methyl-1-phenylhepta-1,6-dien-4-ol

Prepared following the allylation protocol outlined for 7 with Sup22 (1.64 g, 1.80 $\mathrm{mmol}$ ) and a reaction time of 1 hour at room temperature. The crude residue was purified by flash chromatography ( 2.5 to $5 \% \mathrm{EtOAc} / \mathrm{Hex})$ to afford the product as a colorless oil (yield $=84 \%) . \quad \mathrm{R}_{f}=0.33\left(5 \% \mathrm{EtOAc} / \mathrm{PhCH}_{3}\right)$. This compound yielded spectra data consistent with literature reports, see for example: Latuens, M.; Maddess, M. L.; Effiette, L. O. S.; Ouellet, S. G. Org. Lett. 2002, 4, 83.<smiles>CCCOC(=O)/C=C/CC(O)C/C(C)=C/c1ccccc1</smiles>

(40): (+/-)-Methyl (2E,7E)-5-hydroxy-7-methyl-8-phenylocta-2,7-dienoate

Prepared following the cross metathesis protocol outlined for $\mathbf{3 4}$ with 27 (1.95 g, $9.6 \mathrm{mmol}$ ) and a reaction time of 60 minutes. The crude reaction mixture was purified by flash chromatography $(2 \times 10$ to $17 \%$ EtOAc/Hex) to afford two products as colorless oils (yield - Major $2 E=76 \%$, Minor $2 Z=3.4 \%$; $\mathrm{dr}=22: 1)$. $\mathrm{R}_{f}($ Major $2 E)=0.19(17 \%$ EtOAc/Hex); $\mathrm{R}_{f}($ Minor $2 Z)=0.24(17 \%$ EtOAc/Hex).

Major Product - (+/-)-Methyl (2E,7E)-5-hydroxy-7-methyl-8-phenylocta-2,7-dienoate

${ }^{1} \mathrm{H}$ NMR $\left(400 \mathrm{MHz}, \mathrm{CDCl}_{3}\right) \delta 7.36-7.30(\mathrm{~m}, 2 \mathrm{H}), 7.27-7.19(\mathrm{~m}, 3 \mathrm{H}), 6.93$ (ddd, $J=15.6 \mathrm{~Hz}, 7.6 \mathrm{~Hz}, 7.6 \mathrm{~Hz}, 1 \mathrm{H}), 6.38(\mathrm{~s}, 1 \mathrm{H}), 5.87(\mathrm{~d}, J=15.6 \mathrm{~Hz}, 1 \mathrm{H}), 4.02-$ $3.92(\mathrm{~m}, 1 \mathrm{H}), 2.46-2.26(\mathrm{~m}, 4 \mathrm{H}), 1.91(\mathrm{~s}, 3 \mathrm{H}), 1.49(\mathrm{~s}, 9 \mathrm{H}) ;{ }^{13} \mathrm{C}$ NMR $(100 \mathrm{MHz}$, $\left.\mathrm{CDCl}_{3}\right) \delta 165.9,143.9,137.9,135.2,129.1,128.9,128.4,126.6,125.9,80.5,68.2,48.8$, 39.8, 28.4, 18.2; FTIR (neat) ט 3438, 2978, 2933, 1712, 1653, 1367, 1327, 1151, $982 \mathrm{~cm}^{-}$ ${ }^{1}$; HRMS $(\mathrm{m} / \mathrm{z})$ calculated for $\mathrm{C}_{19} \mathrm{H}_{26} \mathrm{O}_{3} 302.1882$, found 302.1877 .

Minor Product - (+/-)-Methyl (2Z,7E)-5-hydroxy-7-methyl-8-phenylocta-2,7-dienoate

${ }^{1} \mathrm{H}$ NMR $\left(400 \mathrm{MHz}, \mathrm{CDCl}_{3}\right) \delta 7.35-7.29(\mathrm{~m}, 2 \mathrm{H}), 7.27-7.23(\mathrm{~m}, 2 \mathrm{H}), 7.22-$ $7.17(\mathrm{~m}, 1 \mathrm{H}), 6.37$ (s, $1 \mathrm{H}), 6.33$ (ddd, $J=11.6 \mathrm{~Hz}, 8.0 \mathrm{~Hz}, 8.0 \mathrm{~Hz}, 1 \mathrm{H}), 5.87$ (d, $J=11.6$ $\mathrm{Hz}, 1 \mathrm{H}), 4.03-3.94(\mathrm{~m}, 1 \mathrm{H}), 2.91-2.78(\mathrm{~m}, 2 \mathrm{H}), 2.57$ (d, $J=3.6 \mathrm{~Hz}, 1 \mathrm{H}), 2.41-2.34$ (m, 2H), 1.91 (s, 3H), 1.49 (s, 9H); ${ }^{13} \mathrm{C}$ NMR (100 MHz, $\left.\mathrm{CDCl}_{3}\right) \delta$ 166.6, 144.4, 138.1, $135.7,129.1,128.4,128.3,126.5,123.9,80.8,69.2,49.1,36.3,28.4,18.3$; FTIR (neat) $\mathrm{U}$ 
$3418,2978,2932,1714,1642,1414,1368,1223,1151,1073 \mathrm{~cm}^{-1}$; HRMS $(\mathrm{m} / z)$ calculated for $\mathrm{C}_{15} \mathrm{H}_{17} \mathrm{O}_{2}\left(\mathrm{M}-\mathrm{C}_{4} \mathrm{H}_{9} \mathrm{O}\right)^{+} 229.1229$, found 229.1221.

For the Preparation of $\mathbf{2 8}$<smiles>COc1ccccc1/C=C/C(O)CCl</smiles>

(Sup23): (+/-)-(3E)-1-Chloro-4-(2-methoxyphenyl)but-3-en-2-ol

Prepared following the addition protocol outlined for Sup1 with 2-methoxy-transcinnamaldehyde $(4.0 \mathrm{~g}, 23.7 \mathrm{mmol})$ in place of trans-cinnamaldehyde and a reaction time of 35 minutes post $n \mathrm{BuLi}$ addition. The crude reaction mixture was purified by flash chromatography (10 to $17 \% \mathrm{EtOAc} / \mathrm{Hex}$ ) to afford the product as a yellow viscous oil (yield $=98 \%) . \quad \mathrm{R}_{f}=0.15(17 \%$ EtOAc/Hex $)$. This compound yielded spectra data consistent with literature reports, see for example: Latuens, M.; Maddess, M. L.; Effiette, L. O. S.; Ouellet, S. G. Org. Lett. 2002, 4, 83.

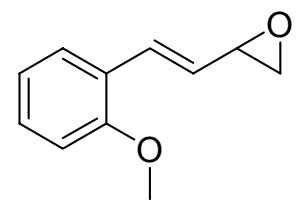

(Sup24): (+/-)-2-[(E)-2-(2-Methoxyphenyl)vinyl]oxirane

Prepared following the ring closure protocol outlined for Sup2 with Sup23 (2.0 g, $9.4 \mathrm{mmol}$ ) in place of Sup1 and a reaction time of 75 minutes. The crude residue was dried under high vacuum to afford the product as a yellow viscous oil in good purity $(>95 \%)$ (yield $=99 \%)$. This compound yielded spectra data consistent with literature reports, see for example: Latuens, M.; Maddess, M. L.; Effiette, L. O. S.; Ouellet, S. G. Org. Lett. 2002, 4, 83.<smiles>C=CCC(O)C/C=C/c1ccccc1OC</smiles>

\section{(28): (+/-)-(1E)-1-(2-Methoxyphenyl)hepta-1,6-dien-4-ol}

Prepared following the allylation protocol outlined for 7 with Sup24 (1.7 g, 9.65 mmol) and a reaction time of 4 hours. The crude residue was purified by flash chromatography (10 to $17 \% \mathrm{EtOAc} / \mathrm{Hex}$ ) to afford the product as a colorless oil (yield = $50 \%) . \quad \mathrm{R}_{f}=0.39\left(10 \% \mathrm{EtOAc} / \mathrm{PhCH}_{3}\right)$. This compound yielded spectra data consistent with literature reports, see for example: Latuens, M.; Maddess, M. L.; Effiette, L. O. S.; Ouellet, S. G. Org. Lett. 2002, 4, 83. 


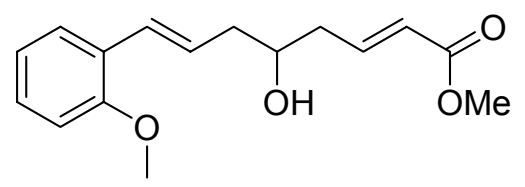

(41): (+/-)-Methyl (2E,7E)-5-hydroxy-8-(2-methoxyphenyl)octa-2,7-dienoate

Prepared following the cross metathesis protocol outlined for $\mathbf{3 4}$ with $\mathbf{2 8}(130 \mathrm{mg}$, $0.56 \mathrm{mmol}$ ) and a reaction time of 50 minutes. The crude reaction mixture was purified by flash chromatography $(25 \% \mathrm{EtOAc} / \mathrm{Hex})$ to afford the product as a light yellow viscous oil (yield $=35 \%) . \quad \mathrm{R}_{f}=0.14(25 \% \mathrm{EtOAc} / \mathrm{Hex}) ;{ }^{1} \mathrm{H}$ NMR $\left(300 \mathrm{MHz}, \mathrm{CDCl}_{3}\right) \delta$ $7.43-7.38(\mathrm{~m}, 1 \mathrm{H}), 7.24-7.16(\mathrm{~m}, 1 \mathrm{H}), 7.02$ (ddd, $J=15.9 \mathrm{~Hz}, 7.5 \mathrm{~Hz}, 7.5 \mathrm{~Hz}, 1 \mathrm{H})$, $6.94-6.82(\mathrm{~m}, 2 \mathrm{H}), 6.80(\mathrm{~d}, J=15.9 \mathrm{~Hz}, 1 \mathrm{H}), 6.19$ (ddd, $J=15.9 \mathrm{~Hz}, 7.5 \mathrm{~Hz}, 7.5 \mathrm{~Hz}$, $1 \mathrm{H}), 5.92(\mathrm{~d}, J=15.9 \mathrm{~Hz}, 1 \mathrm{H}), 3.91-3.80(\mathrm{~m}, 1 \mathrm{H}), 3.83(\mathrm{~s}, 3 \mathrm{H}), 3.72(\mathrm{~s}, 3 \mathrm{H}), 2.51-$ $2.30(\mathrm{~m}, 4 \mathrm{H}), 2.25$ (brs, $1 \mathrm{H}) ;{ }^{13} \mathrm{C}$ NMR $\left(75 \mathrm{MHz}, \mathrm{CDCl}_{3}\right) \delta 167.1,156.7,145.9,128.7$, 128.6, 126.9, 126.4, 123.6, 120.9, 111.1, 70.1, 55.7, 51.8, 41.5, 39.8; FTIR (neat) ט 3436, 2950, 2838, 1715, 1659, 1489, 1436, 1243, 1029, $976 \mathrm{~cm}^{-1}$; HRMS $(\mathrm{m} / \mathrm{z})$ calculated for $\mathrm{C}_{16} \mathrm{H}_{20} \mathrm{O}_{4} 276.1362$, found 276.1371.

For the Preparation of $\mathbf{2 9}$<smiles>OC(C=C(c1ccccc1)c1ccccc1)CCl</smiles>

\section{(Sup25): (+/-)-1-Chloro-4,4-diphenylbut-3-en-2-ol}

Prepared following the addition protocol outlined for Sup1 with $\beta$-phenyl-transcinnamaldehyde $(698 \mathrm{mg}, 3.35 \mathrm{mmol})$ in place of trans-cinnamaldehyde and a reaction time of 90 minutes post $n \mathrm{BuLi}$ addition. The crude reaction mixture was purified by flash chromatography $(10 \% \mathrm{EtOAc} / \mathrm{Hex})$ to afford the product as a light yellow viscous oil (yield $=93 \%) . \quad \mathrm{R}_{f}=0.43(17 \% \mathrm{EtOAc} / \mathrm{Hex})$. This compound yielded spectra data consistent with literature reports, see for example: Latuens, M.; Maddess, M. L.; Effiette, L. O. S.; Ouellet, S. G. Org. Lett. 2002, 4, 83.<smiles>C(=C(c1ccccc1)c1ccccc1)C1CO1</smiles>

(Sup26): (+/-)-2-(2,2-Diphenylvinyl)oxirane

Prepared following the ring closure protocol outlined for Sup2 with Sup25 (730 $\mathrm{mg}, 2.83 \mathrm{mmol}$ ) in place of $\mathbf{S u p} \mathbf{1}$ and a reaction time of 90 minutes. The crude residue was dried under high vacuum to afford the product as a yellow viscous oil in good purity $(>95 \%)$ (yield $=95 \%)$. This compound yielded spectra data consistent with literature reports, see for example: Latuens, M.; Maddess, M. L.; Effiette, L. O. S.; Ouellet, S. G. Org. Lett. 2002, 4, 83. 
<smiles>C=CCC(O)CC=C(c1ccccc1)c1ccccc1</smiles>

(29): (+/-)-1,1-Diphenylhepta-1,6-dien-4-ol

Prepared following the allylation protocol outlined for 7 with Sup26 (151 mg, $0.68 \mathrm{mmol}$ ) and a reaction time of 1 hour. The crude residue was purified by flash chromatography $\left(5 \% \mathrm{EtOAc} / \mathrm{PhCH}_{3}\right)$ to afford the product as a colorless oil (yield = $85 \%) . \quad \mathrm{R}_{f}=0.65\left(10 \% \mathrm{EtOAc} / \mathrm{PhCH}_{3}\right)$. This compound yielded spectra data consistent with literature reports, see for example: Latuens, M.; Maddess, M. L.; Effiette, L. O. S.; Ouellet, S. G. Org. Lett. 2002, 4, 83.<smiles>COC(=O)/C=C/CC(O)CC=C(c1ccccc1)c1ccccc1</smiles>

(42): (+/-)-Methyl (2E)-5-hydroxy-8,8-diphenylocta-2,7-dienoate

Prepared following the cross metathesis protocol outlined for $\mathbf{3 4}$ with $\mathbf{2 9}(130 \mathrm{mg}$, $0.56 \mathrm{mmol}$ ) and a reaction time of 50 minutes. The crude reaction mixture was purified by flash chromatography ( 10 to $17 \% \mathrm{EtOAc} / \mathrm{Hex}$ ) to afford the product as a colorless oil (yield $=84 \%) . \quad \mathrm{R}_{f}=0.20(17 \% \mathrm{EtOAc} / \mathrm{Hex}) ;{ }^{1} \mathrm{H}$ NMR $\left(400 \mathrm{MHz}, \mathrm{CDCl}_{3}\right) \delta 7.39-7.15$ (m, 10H), 6.93 (ddd, $J=15.6 \mathrm{~Hz}, 7.6 \mathrm{~Hz}, 7.6 \mathrm{~Hz}, 1 \mathrm{H}), 6.13$ (dd, $J=7.6 \mathrm{~Hz}, 7.6 \mathrm{~Hz}, 1 \mathrm{H}$ ), $5.87(\mathrm{~d}, J=15.6 \mathrm{~Hz}, 1 \mathrm{H}), 3.92-3.84(\mathrm{~m}, 1 \mathrm{H}), 3.71(\mathrm{~s}, 3 \mathrm{H}), 2.44-2.26(\mathrm{~m}, 4 \mathrm{H}), 1.82(\mathrm{~d}$, $J=4.0 \mathrm{~Hz}, 1 \mathrm{H}) ;{ }^{13} \mathrm{C}$ NMR $\left(100 \mathrm{MHz}, \mathrm{CDCl}_{3}\right) \delta 166.7,145.3,144.8,142.3,139.7,129.9$, $128.4,128.2,127.3,127.3,127.2,124.4,123.6,70.6,51.5,39.7,37.5$; FTIR (neat) $\mathrm{u}$ 3436, 3056, 3024, 2950, 1715, 1659, 1495, 1442, 1329, 1275, 1201, 1043, 762, $702 \mathrm{~cm}^{-1}$; HRMS $(m / z)$ calculated for $\mathrm{C}_{21} \mathrm{H}_{22} \mathrm{O}_{3} 322.1569$, found 322.1559 .<smiles>C=C[C@H](C)[C@@H](O)C/C(C)=C/c1ccccc1</smiles>

(30): (+/-)-(1E,4S,5S)-2,5-Dimethyl-1-phenylhepta-1,6-dien-4-ol

A $25 \mathrm{~mL}$ round bottom flask was flame dried under a stream of nitrogen and allowed to cool to room temperature. It was then charged with Sup22 (160 mg, 1.0 mmol) and THF $(3 \mathrm{~mL})$. To the resulting solution was added potassium $Z$ crotyltrifluoroborate $(243 \mathrm{mg}, 1.5 \mathrm{mmol})$ and the heterogeneous mixture was cooled to 0 ${ }^{\circ} \mathrm{C}$. $\mathrm{BF}_{3} \cdot \mathrm{OEt}_{2}(25 \mu \mathrm{L}, 0.2 \mathrm{mmol})$ was added dropwise and the reaction was followed by TLC. After 3 hours an approximately equal volume of brine was added and the reaction contents transferred to a separatory funnel with ether. The organic layer was isolated and the aqueous layer extracted with ether. The combined organics were dried with $\mathrm{MgSO}_{4}$ filtered and concentrated in vacuo. The crude residue was purified by flash chromatography $(10 \% \mathrm{EtOAc} / \mathrm{Hex})$ to yield the product as a colorless oil (yield $=75 \%$ ) and a single diastereomer by ${ }^{1} \mathrm{H}$ NMR. $\mathrm{R}_{f}=0.10(10 \% \mathrm{EtOAc} / \mathrm{Hex}) ;{ }^{1} \mathrm{H} \mathrm{NMR}(400 \mathrm{MHz}$, $\left.\mathrm{CDCl}_{3}\right) \delta 7.33-7.28(\mathrm{~m}, 2 \mathrm{H}), 7.25-7.16(\mathrm{~m}, 3 \mathrm{H}), 6.36(\mathrm{~s}, 1 \mathrm{H}), 5.84(\mathrm{ddd}, J=17.6 \mathrm{~Hz}$, 
$10.4 \mathrm{~Hz}, 7.6 \mathrm{~Hz}, 1 \mathrm{H}), 5.12-5.04(\mathrm{~m}, 2 \mathrm{H}), 3.69$ (ddd, $J=9.2 \mathrm{~Hz}, 5.6 \mathrm{~Hz}, 3.2 \mathrm{~Hz}, 1 \mathrm{H})$, $2.44-2.38(\mathrm{~m}, 1 \mathrm{H}), 2.36-2.27(\mathrm{~m}, 1 \mathrm{H}), 2.20-2.13(\mathrm{~m}, 1 \mathrm{H}), 1.89$ (s, 3H), 1.82 (brs, $1 \mathrm{H}), 1.10(\mathrm{~d}, J=6.8 \mathrm{~Hz}, 3 \mathrm{H}) ;{ }^{13} \mathrm{C} \mathrm{NMR}\left(100 \mathrm{MHz}, \mathrm{CDCl}_{3}\right) \delta 141.0,138.0,136.0,128.9$, $128.2, \quad 128.2, \quad 126.3, \quad 115.2, \quad 72.1, \quad 45.9, \quad 43.5, \quad 18.0, \quad 14.9 ; \quad$ FTIR (neat) v $3443,3080,2973,1641,1599,1492,1444,1385,1051,998,916 \mathrm{~cm}^{-1}$; HRMS $(\mathrm{m} / \mathrm{z})$ calculated for $\mathrm{C}_{15} \mathrm{H}_{20} \mathrm{O} 216.1514$, found 216.1519 .

For the Preparation of $\mathbf{3 1}$<smiles>OC(CCl)C1=CCCCC1</smiles>

\section{(Sup27): (+/-)-2-Chloro-1-cyclohex-1-en-1-ylethanol}

Prepared following the addition protocol outlined for Sup1 with 1-cyclohexne-1carboxaldehyde (1.04 g, $9.44 \mathrm{mmol})$ in place of trans-cinnamaldehyde and a reaction time of 90 minutes post $n \mathrm{BuLi}$ addition. The crude reaction mixture was purified by flash chromatography $\left(15 \% \mathrm{Et}_{2} \mathrm{O} / \mathrm{Hex}\right)$ to afford the product as a colorless oil (yield $=$ $79 \%) . \mathrm{R}_{f}=0.48\left(30 \% \mathrm{Et}_{2} \mathrm{O} / \mathrm{Hex}\right)$. This compound yielded spectra data consistent with literature reports, see for example: Latuens, M.; Maddess, M. L.; Effiette, L. O. S.; Ouellet, S. G. Org. Lett. 2002, 4, 83.

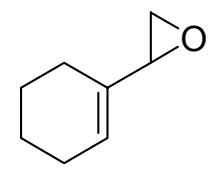

\section{(Sup28): (+/-)-2-Chloro-1-cyclohex-1-en-1-ylethanol}

Prepared following the ring closure protocol outlined for Sup2 with Sup27 (1.34 $\mathrm{g}, 8.34 \mathrm{mmol}$ ) in place of Sup1 and a reaction time of $12 \mathrm{~h}$ at room temperature. This reaction would not proceed to competition and the reaction mixture after drying under high vacuum was a mixture of the desired product and starting material $(2: 1,96 \%$ recovery). This mixture was purified by flash chromatography $\left(1 \% \mathrm{Et}_{3} \mathrm{~N}, 98\right.$ Pentane : 2 Ether) to yield the product as a colorless oil $(54 \%) ; \mathrm{R}_{f}=0.55(15 \%$ Ether/Hex). This compound yielded spectra data consistent with literature reports, see for example: Latuens, M.; Maddess, M. L.; Effiette, L. O. S.; Ouellet, S. G. Org. Lett. 2002, 4, 83.<smiles>C=CC[C@@H](O)CC1=CCCCC1</smiles>

\section{(31): (2S)-1-Cyclohex-1-en-1-ylpent-4-en-2-ol}

Prepared following the allylation protocol outlined for 26 with Sup28 (175 mg, $1.41 \mathrm{mmol})$ in place of Sup20 and (+)-Ipc $\mathrm{ISAllyl}_{2}$ in place of (-)-Ipc ${ }_{2}$ BAllyl. The crude residue was purified by flash chromatography $\left(10 \% \mathrm{Et}_{2} \mathrm{O} /\right.$ pentane). The isolated product was a colorless oil (yield $=92 \%$ ); $\mathrm{R}_{f}=0.26\left(15 \% \mathrm{Et}_{2} \mathrm{O} / \mathrm{Hex}\right)$. GC (beta dex, temperature ramp $35{ }^{\circ} \mathrm{C}$ hold for $15 \mathrm{~min}$, then $35{ }^{\circ} \mathrm{C}$ to $100{ }^{\circ} \mathrm{C}$ at $3{ }^{\circ} \mathrm{C} / \mathrm{min}$, then $100{ }^{\circ} \mathrm{C}$ to $130{ }^{\circ} \mathrm{C}$ at $\left.0.5^{\circ} \mathrm{C} / \mathrm{min}\right) \mathrm{RT}_{1}=81.1 \mathrm{~min}, \mathrm{RT}_{2}=82.4 \mathrm{~min} ;$ ee $=96 \% ;[\alpha]^{20}{ }_{\mathrm{D}}=+12.2^{\circ}(\mathrm{c}=1.2$, 
$\mathrm{CHCl}_{3}$ ). This compound yielded spectra data consistent with literature reports, see for example: Latuens, M.; Maddess, M. L.; Effiette, L. O. S.; Ouellet, S. G. Org. Lett. 2002, 4,83 .<smiles>COC(=O)/C=C/C[C@@H](O)CC1=CCCCC1</smiles>

(44): Methyl (2E,5S)-6-cyclohex-1-en-1-yl-5-hydroxyhex-2-enoate

Prepared following the cross metathesis protocol outlined for 34 with 31 (149 mg, $0.9 \mathrm{mmol}$ ) and a reaction time of 50 minutes. The crude reaction mixture was purified by flash chromatography (10 to $17 \%$ EtOAc/Hex) to afford the product as a yellow oil (yield $=54 \%, 72 \%$ based on recovered starting material $) . \mathrm{R}_{f}=0.22(17 \%$ EtOAc/Hex $) ;{ }^{1} \mathrm{H}$ NMR $\left(400 \mathrm{MHz}, \mathrm{CDCl}_{3}\right) \delta 6.97(\mathrm{ddd}, J=16.0 \mathrm{~Hz}, 7.6 \mathrm{~Hz}, 7.6 \mathrm{~Hz}, 1 \mathrm{H}), 5.87(\mathrm{~d}, J=16.0$ $\mathrm{Hz}, 1 \mathrm{H}), 5.51-5.45(\mathrm{~m}, 1 \mathrm{H}), 3.83-3.75(\mathrm{~m}, 1 \mathrm{H}), 3.68(\mathrm{~s}, 3 \mathrm{H}), 2.38-2.26(\mathrm{~m}, 2 \mathrm{H}), 2.12$ $-1.77(\mathrm{~m}, 7 \mathrm{H}), 1.61-1.46(\mathrm{~m}, 4 \mathrm{H}) ;{ }^{13} \mathrm{C} \mathrm{NMR}\left(100 \mathrm{MHz}, \mathrm{CDCl}_{3}\right) \delta 167.0,146.0,134.3$, 125.6, 123.3, 67.7, 51.6, 46.3, 39.8, 28.5, 25.5, 23.0, 22.5; FTIR (neat) ৩ 3441, 2926, $1722,1656,1437,1273,1200,1045,979 \mathrm{~cm}^{-1}$; HRMS $(\mathrm{m} / z)$ calculated for $\mathrm{C}_{13} \mathrm{H}_{20} \mathrm{O}_{3}$ 224.1412, found 224.1413. HPLC (CHIRALPAK AD, $1 \mathrm{~mL} / \mathrm{min}, 96.5 \mathrm{Hex}: 3.5 \mathrm{iPa}, 30$ ${ }^{\circ} \mathrm{C}, 1 \mu \mathrm{L}$ injection) $\mathrm{RT}_{1}=16.5 \mathrm{~min}, \mathrm{RT}_{2}=19.3 \mathrm{~min}$; ee $=96 \%$.

For the Preparation of $\mathbf{3 2}$

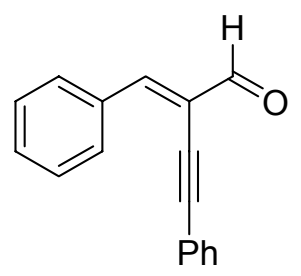

(Sup29): (2E)-2-Benzylidene-4-phenylbut-3-ynal

A dry $50 \mathrm{~mL}$ round bottom flask was charged with $\mathrm{Pd}\left(\mathrm{PPh}_{3}\right)_{4}(274 \mathrm{mg}, 0.24$ $\mathrm{mmol})$. To this was added freshly distilled THF $(5 \mathrm{~mL})$ and $\mathrm{Et}_{3} \mathrm{~N}(5 \mathrm{~mL})$. The mixture was set stirring and $\alpha$-bromocinnamaldehyde (1.0 g, $4.74 \mathrm{mmol})$ was added along with copper iodide $(190.3 \mathrm{mg}, 0.47 \mathrm{mmol})$. Finally phenyl acetylene $(637 \mu \mathrm{L}, 5.69 \mathrm{mmol})$ was added dropwise. The reaction was left for three hours at room temperature then quenched with $\mathrm{NH}_{4} \mathrm{Cl}_{\mathrm{aq}}$. Ether was added and the reaction mixture transferred to a separatory funnel. The organic residue was isolated, the aqueous layer back extracted with ether, the organics combined, and the solvent removed in vacuo. The crude residue was purifed by flash chromatography $(10 \% \mathrm{EtOAc} / \mathrm{Hex})$ to afford the product as an orange oil (yield $=93 \%) ; \mathrm{R}_{f}=0.48(17 \%$ EtOAc/Hex). This compound yielded spectra data consistent with literature reports, see for example: Latuens, M.; Maddess, M. L.; Effiette, L. O. S.; Ouellet, S. G. Org. Lett. 2002, 4, 83. 
<smiles>OC(CCl)/C(C#Cc1ccccc1)=C\c1ccccc1</smiles>

(Sup30): (+/-)-(3E)-3-Benzylidene-1-chloro-5-phenylpent-4-yn-2-ol

Prepared following the addition protocol outlined for Sup1 with Sup29 (1.02 g, $4.3 \mathrm{mmol}$ ) in place of trans-cinnamaldehyde and a reaction time of 60 minutes post $n \mathrm{BuLi}$ addition. The crude reaction mixture was purified by flash chromatography $(10 \%$ EtOAc/Hex) to afford the product as a yellow oil (yield $=86 \%) . \quad \mathrm{R}_{f}=0.31 \quad(17 \%$ $\mathrm{EtOAc/Hex).} \mathrm{This} \mathrm{compound} \mathrm{yielded} \mathrm{spectra} \mathrm{data} \mathrm{consistent} \mathrm{with} \mathrm{literature} \mathrm{reports,} \mathrm{see}$ for example: Latuens, M.; Maddess, M. L.; Effiette, L. O. S.; Ouellet, S. G. Org. Lett. 2002, 4, 83 .

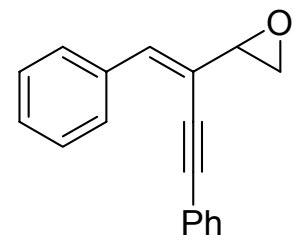

(Sup31): (+/-)-2-[(1E)-1-Benzylidene-3-phenylprop-2-ynyl]oxirane

Prepared following the ring closure protocol outlined for Sup2 with Sup30 (1.04 $\mathrm{g}, 3.68 \mathrm{mmol}$ ) in place of Sup1 and a reaction time of 90 minutes. The crude residue was purified by flash chromatography $\left(5 \% \mathrm{Et}_{3} \mathrm{~N}, 9 \mathrm{Hex}: 1 \mathrm{EtOAc}\right)$ to afford the product as a yellow oil (yield $=85 \%) ; \mathrm{R}_{f}=0.62(17 \%$ EtOAc/Hex). This compound yielded spectra data consistent with literature reports, see for example: Latuens, M.; Maddess, M. L.; Effiette, L. O. S.; Ouellet, S. G. Org. Lett. 2002, 4, 83.<smiles>C=CCC(O)CC(C#Cc1ccccc1)=Cc1ccccc1</smiles>

\section{(32): (+/-)-(6Z)-6-Benzylidene-8-phenyloct-1-en-7-yn-4-ol}

Prepared following the allylation protocol outlined for 7 with Sup31 (168 mg, $0.68 \mathrm{mmol}$ ) and a reaction time of 12 hours. The crude residue was purified by flash chromatography $(5 \%$ EtOAc/Hex) to yield the product as a colorless oil (yield $=46 \%) ; \mathrm{R}_{f}$ $=0.47(10 \% \mathrm{EtOAc} / \mathrm{Hex})$. This compound yielded spectra data consistent with literature reports, see for example: Latuens, M.; Maddess, M. L.; Effiette, L. O. S.; Ouellet, S. G. Org. Lett. 2002, 4, 83 . 
For the Preparation of $\mathbf{3 3}$

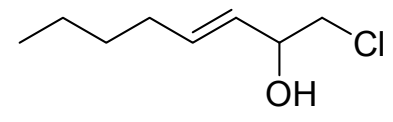

\section{(Sup32): (+/-)-(3E)-1-Chlorooct-3-en-2-ol}

Prepared following the addition protocol outlined for Sup1 with trans-2-heptenal $(1.31 \mathrm{~mL}, 10 \mathrm{mmol})$ in place of trans-cinnamaldehyde and a reaction time of 90 minutes post $n \mathrm{BuLi}$ addition. The crude reaction mixture was purified by flash chromatography $\left(10 \% \mathrm{Et}_{2} \mathrm{O} / \mathrm{Hex}\right)$ to afford the product as a colorless oil (yield $\left.=88 \%\right) . \mathrm{R}_{f}=0.27(10 \%$ EtOAc/Hex). This compound yielded spectra data consistent with literature reports, see for example: Latuens, M.; Maddess, M. L.; Effiette, L. O. S.; Ouellet, S. G. Org. Lett. 2002, 4, 83 .

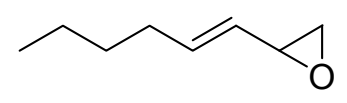

(Sup33): (+/-)-2-[(1E)-Hex-1-enyl]oxirane

Prepared following the ring closure protocol outlined for Sup2 with Sup32 (1.25 g, $7.68 \mathrm{mmol}$ ) in place of Sup1 and a reaction time of 90 minutes. The crude residue was dried under high vacuum for 2 minutes to afford the product as a colorless oil in good purity $(>90 \% \sim 5 \%$ THF present) (yield $=98 \%$ ). This compound yielded spectra data consistent with literature reports, see for example: Latuens, M.; Maddess, M. L.; Effiette, L. O. S.; Ouellet, S. G. Org. Lett. 2002, 4, 83.

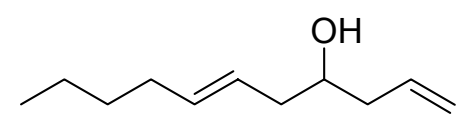

\section{(33): (+/-)-(6E)-Undeca-1,6-dien-4-ol}

Prepared following the allylation protocol outlined for 7 with Sup33 (200 mg, $1.58 \mathrm{mmol}$ ) and a reaction time of 1 hour. The crude residue was purified by flash chromatography $\left(20 \% \mathrm{Et}_{2} \mathrm{O} / \mathrm{Hex}\right)$ to yield the product as a colorless oil (yield $\left.=77 \%\right)$. $\mathrm{R}_{f}$ $=0.26\left(10 \% \mathrm{Et}_{2} \mathrm{O} /\right.$ pentane $)$. This compound yielded spectra data consistent with literature reports, see for example: Latuens, M.; Maddess, M. L.; Effiette, L. O. S.; Ouellet, S. G. Org. Lett. 2002, 4, 83. 